\title{
There's no harm in having too much: A comprehensive toolbox of methods in trophic ecology
}

Nabil Majdi ${ }^{\text {a, b, c, } 1 \text {, Nicolas Hette-Tronquart }}{ }^{\mathrm{a}, \mathrm{d}}$,, 1 , Etienne Auclaira, e , Alexandre Bec $^{\mathrm{a}, \mathrm{f}}$, Tiphaine Chouvelon ${ }^{\mathrm{a}, \mathrm{g}}$, Bruno Cognie ${ }^{\mathrm{a}, \mathrm{i}}$, Michael Dangera, h, Priscilla Decottignies ${ }^{\mathrm{a}, \mathrm{i}}$, Aurélie Dessier ${ }^{\mathrm{a}, \mathrm{j}}$, Christian Desvilettes ${ }^{\mathrm{a}, \mathrm{f}}$, Stanislas Dubois ${ }^{\mathrm{a}, \mathrm{k}}$, Christine Dupuya, ${ }^{\mathrm{a}}$, Clémentine Fritsch ${ }^{\mathrm{a}, 1}$, Cédric Gaucherel ${ }^{\mathrm{a}, \mathrm{m}}$, Mickaël Hedde $^{\mathrm{a}, \mathrm{n}}$, Franck Jabot ${ }^{\mathrm{a}, \mathrm{o}}$, Sebastien Lefebvre ${ }^{\mathrm{a}, \mathrm{p}}$, q, Martin P. Marzloffa, k, Benjamin Pey ${ }^{\mathrm{c}}$, Nathalie Peyrard ${ }^{\mathrm{a}, \mathrm{e}}$, Thibaut Powolny ${ }^{\mathrm{a}, 1}$, Régis Sabbadin ${ }^{\mathrm{a}, \mathrm{e}}$, Elisa Thébault ${ }^{\mathrm{a}, \mathrm{r}}$, Marie-Elodie Perga ${ }^{\mathrm{a}, \mathrm{s}}$

a GRET (Groupe de Recherche en Ecologie Trophique), GDR 3716 CNRS INEE INRA, France

${ }^{\mathrm{b}}$ Universität Bielefeld, Abteilung Tierökologie, Konsequenz 45, 33615 Bielefeld, Germany

${ }^{c}$ Université de Toulouse, EcoLab, UMR 5245 CNRS, INP, UPS, ENSAT, 118 route de Narbonne, 31062 Toulouse, France

${ }^{\mathrm{d}}$ Irstea, UR HYCAR, 1 rue Pierre Gilles-de-Gennes, 92160 Antony, France

e INRA - MIAT, UR 875, INRA, 24, Chemin de Borde Rouge, 31320 Castanet-Tolosan, France

${ }^{\mathrm{f}}$ Université Clermont Auvergne, CNRS, LMGE, 1 impasse Amélie Murat, 63178 Aubière, France

${ }^{g}$ IFREMER - BE, LBCM, Centre Atlantique, rue de l'̂́le d'Yeu, 44311 Nantes, France

${ }^{\text {h }}$ Université de Lorraine, LIEC, UMR 7360 CNRS, rue Claude Bernard, 57070 Metz, France

${ }^{1}$ Université de Nantes, IUML Mer-Molécules-Santé (MMS), UMR 3473 CNRS, 2 rue de la Houssinière, 44322 Nantes, France

${ }^{j}$ Université de La Rochelle, LIENSs, UMR 7266 CNRS, 2 rue Olympe de Gouges, 17000 La Rochelle, France

${ }^{\mathrm{k}}$ IFREMER - DYNECO, LEBCO, Centre de Bretagne, CS 10070, 29280 Plouzané, France

${ }^{1}$ Université Bourgogne Franche-Comté, Chrono-environnement, UMR 6249 CNRS, INRA, 16 route de Gray, 25030 Besançon, France

${ }^{\mathrm{m}}$ Université Montpellier, AMAP - INRA, CIRAD, CNRS, IRD, Montpellier, France

${ }^{\mathrm{n}}$ INRA - Eco\&Sols, UMR 1222, 2 Place Viala, 34060 Montpellier, France

${ }^{\circ}$ Irstea, UR LISC, Campus des Cézeaux, 9 avenue Blaise Pascal, 63178 Aubière, France

${ }^{\mathrm{p}}$ Université de Lille, LOG, UMR 8187 CNRS, ULCO, 28 Avenue Foch, 62930 Wimereux, France

${ }^{\mathrm{q}}$ IFREMER - Laboratoire Ressources Halieutiques, 150 Quai Gambetta, 62321 Boulogne-sur-mer, France

${ }^{\mathrm{r}}$ Université Pierre et Marie Curie, Institute of Ecology and Environmental Sciences, CNRS, Sorbonne Universités, Paris, France

${ }^{s}$ University of Lausanne, Institute of Earth surface Dynamics, Lausanne, Switzerland

\section{A R T I C L E I N F O}

\section{Keywords:}

Food web

Feeding interactions

Flux of energy

Computer simulations

Trophic models

\begin{abstract}
A B S T R A C T
Trophic ecology is the study of feeding interactions and food acquisition by organisms. It includes the causes and consequences of those behaviours at all levels of biological organisation. As a field of research, it crosses many disciplinary boundaries and provides knowledge that is pertinent to many other areas of ecology. Here we list and categorise the methods available to trophic ecologists whose toolbox has broadened considerably in recent years. They encompass empirical and numerical approaches with focus ranging from molecules to ecosystems. We further examine the relationship of each method to features such as the scale of observation (from microbes to largest organisms) and organisational level (from individuals to ecosystems) as well as the ecological question the method is capable of answering (from detecting predator-prey relationships to studying implications and consequences at different scales). Our survey reveals a very wide range of methodologies, each more-or-less appropriate for a particular line of research. It also identifies deficits, for example, trophic interactions at microscopic scales, for which empirical methods have hardly been used, as well as trophic models that have failed to consider fluxes at the ecosystem scale. Furthermore, we note that the combination of methodologies remains under-exploited despite great opportunities to solve complex ecological questions and to foster the emergence of new insights and hypotheses regarding organism, population and/or ecosystem properties.
\end{abstract}

\footnotetext{
* Corresponding author at: GRET (Groupe de Recherche en Ecologie Trophique), GDR 3716 CNRS INEE INRA, France.

Email address: nicolas.hette@edu.mnhn.fr (N. Hette-Tronquart)

1 The authors contributed equally to this paper.
} 


\section{Introduction}

Trophic ecology covers the ecological implications of feeding. As such, it embraces the act of food acquisition and its consequences at the individual, population and community levels up to functional outputs at the scale of the whole ecosystem. The field of trophic ecology, in which the concept of food web is embedded, is broader than organismal detection and the description of inter-species feeding relationships. Briefly, at the smallest organisational levels, feeding is intimately linked to nutrition and ecophysiology, as the quantity and quality of mineral or organic food resources regulates individual survival, growth and fecundity with upscaling effects on population demography (Elser et al., 1996). Except for lithotrophic and saprophytic organisms, food acquisition also implies that feeding interactions generate reciprocal effects on predator and prey demography (Lotka, 1925; Volterra, 1926). Trophic relationships are also responsible for species inter-dependencies and contribute to shaping behaviours, driving phenotype selection and eco-evolutionary feedbacks (Post and Palkovacs, 2009; Clinchy et al., 2013). A trophic transition can also be biogeochemically regarded as a way to transfer mineral or organic matter between two trophic levels with more-or-less efficiency ("trophic efficiency concept" of Lindeman, 1942, "ecological stoichiometry" see e.g. Elser et al., 1996), or transformations in its biochemical quality ("trophic upgrading": Klein-Breteler et al., 1999). The concept of food web brings trophic ecology to the community and ecosystem scales. Food webs allows exploring the network of consumer-resource interactions, considering its assemblage rules and interaction strength and the consequences of network structure to overall community composition and stability, up to emergent properties of the ecosystem - like carbon fixation (see Layman et al., 2015, and references therein for a synthesis of major concept achievements in food web ecology).

The broadness of trophic ecology implies a diversity of methodologies, along with considerable improvements and developments both in field and laboratory methods. In addition, numerical approaches have flourished and now support trophic ecologists in their efforts to conceptualise their theories and to modify them based on empirical data (e.g. Proulx et al., 2005; D'Alelio et al., 2016).

Considering this large and fast-evolving bouquet of methodologies, we felt that an up-to-date overview of existing methods, merging both empirical and numerical technics, has been so far missing. Here, by providing a technical overview, we hope to facilitate both upstream decision-making and the inclusion of a broader diversity of research paths within otherwise well-defined methodological road maps. Nevertheless, we do not pretend to provide either an exhaustive critical review of every method relevant to trophic ecology or systematic pairwise comparisons of all methods. For this, we refer readers to the comprehensive book by Garvey and Whiles (2017) and to more specific methodological reviews referenced hereafter. Because the choice of a method primarily depends on its ability to answer a question at hand, we have structured this review accordingly, grouping the methodologies into four categories based on the trophic ecology question they are most suitable for addressing: (Section 2) empirical detection of predator-prey relationships or food sources, (Section 3) connection of species within networks based on empirical data (inference methods), (Section 4) quantification of the consequences of feeding, from individuals to ecosystems and ( Section 5) testing the implications of trophic interactions (trophic models). For each method, we briefly describe the aims and principles, the advantages and drawbacks, and we include estimates of human and financial costs, as time and money are often decisive in the final choice. Beyond providing a methodological toolbox that will help identify the most appropriate tool (Section 6), we seek to encourage an integrated research strategy that combines approaches
(Section 7) and to highlight the conceptual barriers (Section 8) in trophic ecology.

\section{Detecting predator-prey relationships or food sources}

\subsection{Observations of feeding activity}

The most straightforward and oldest approach to study feeding interactions relies on observations. Feeding observations can be made with the naked eye and simple equipment (e.g., binoculars) or using sophisticated, miniaturised, high-magnification optical devices, including remote underwater video stations, camera traps and drones (e.g. Linchant et al., 2015). This allows large-scale records of feeding behaviours in remote ecosystems that are poorly studied. In addition, animal-borne video systems offer the animal's perspective (e.g. Moll et al., 2007). For microscopic or suspension-feeding animals, most observations are restricted to laboratory conditions, for example using a camera attached to a microscope (e.g. Dupuy et al., 2010) or by in vivo video endoscopy (e.g. Prasetiya et al., 2017). To complement direct observations, an emerging approach consists in remotely monitoring multiple biological and environmental factors that constitute surrogates for feeding activity, such as the movements of body parts, oesophageal or gastric temperatures and geographical positions, using animal-attached bio-logging devices (Ropert-Coudert and Wilson, 2005). This should further progress with the transfer of geo-referenced human mobility data analysis techniques to animals (Thums et al., 2018). If direct observation of feeding activity is impracticable, food intake can be inferred from the disappearance of food items. For example, suspension-feeder activity is most commonly assessed using food-clearance experiments or flow-through chamber methods (see e.g. Ward and Shumway, 2004). Different parameters can be obtained this way, such as clearance rate, retention and sorting efficiencies, ingestion, and egestion rates.

\subsection{Gut content and faeces analysis}

Observing the food remains in digestive tracts of animals is the most common approach to get a basic, timely knowledge of predator-prey relationships. Some studies have used massive gut contents datasets to evaluate and compare trophic networks in different ecosystems (e.g. Winemiller, 1990). Especially in fishes, typical methodologies and indices have been developed, and some like the percentage of prey occurrence may emerge as relatively reliable proxies of diet composition (see Baker et al., 2014). Rejection pellets and faeces can also be collected and inspected for undigested prey items (e.g. Kusmer, 1990). In most cases, a dietary assessment is based on the recovery of hard/recalcitrant prey parts (e.g. bones, fur, diatom frustules), which makes a reference collection of such parts often necessary to identify the respective prey organism.

The main advantages of this type of dietary analysis consist in: (1) being accessible, (2) being applicable at relatively large spatial and temporal scales and (3) enabling assessments of prey size (e.g. measuring otoliths or vertebrae). Among the main drawbacks are (1) the discrepancies in taxonomic distinctness (as the ingested items can be identified either at the species level or at a higher taxonomic level), (2) the inability to account for labile food items and (3) the requirement of comprehensive taxonomic expertise. (4) Ethical issues are also raised by this approach, particularly when animals must be dissected. Alternative techniques that avoid dissection can be used to recover stomach contents, such as stomach flushing or regurgitation (e.g. Pierce and Boyle, 1991; Legler and Sullivan, 1979; Duffy and Jackson, 1986). In addition, as many microscopic animals have transparent bodies, their 
gut contents can often be examined under the microscope without dissection. For example, confocal laser scanning microscopy can be used to detect the auto-fluorescence of micro-algal pigments in the gut of rotifers (Mialet et al., 2013), and chromatography to quantify ingested biomarker pigments extracted from guts (e.g. Majdi et al., 2012).

Molecular approaches can also be used to decipher ingested prey remains based on the use of specific prey primers to amplify the prey DNA contained in the gut or faeces of the predator followed by (meta)barcoding (for a review see King et al., 2008). The use of molecular gut content has really expanded in recent years and has proved useful to assess, for instance, the diet of minute animals such as soil micro- and meso-arthropods (e.g. Eitzinger et al., 2013; Heidemann et al., 2014), and zooplankton (e.g. Ho et al., 2017). The major advantages of analysing gut content DNA are: (1) high taxonomic resolution without taxonomic expertise, (2) the inclusion of partly digested, unidentifiable prey chunks and, potentially, (3) the acquisition of data on the microbial assemblages ingested or persisting in the gut (i.e. gut microbiomes, see, e.g. Derycke et al., 2016). However, besides substantial costs, there are several disadvantages inherent to molecular approaches, especially (1) high risk of sample contamination and false positives, (2) need for specific primers to identify uncommon prey taxa, (3) absence in public gene repositories of sequence data for the DNA of numerous prey types, (4) bias in quantitative extrapolations due to the differential timing of DNA degradation during digestion or the specificity of certain DNA extraction protocols and (5) the inability to detect cannibalistic behaviour (Traugott et al., 2013).

\subsection{Parasites as biological tags}

Since some parasites are transmitted only through food ingestion, they serve as evidence of a feeding interaction and indicate that the host species has fed in geographical areas where the prevalence of this parasite is high. Similarly, accurate information about the feeding grounds and past movements of animal hosts can be surmised based on the presence of multiple parasite species differing in their endemic areas (MacKenzie and Abaunza, 1998). Yet, to be reliable biological tags, parasites must have: (1) distinct prevalences in different studied areas, (2) limited inter-annual or seasonal variations in those prevalences, (3) a high specificity for the microhabitat within the host's body, (4) a lifespan fitting the aim/scale of the study, (5) no strong pathological effects on the host and (6) preferably, a direct and single-host life cycle (facilitating interpretations). They must also be readily detectable and identifiable. Helminths generally fulfil all of these criteria and are thus the most commonly used trophic tracers (see MacKenzie, 2002).

The use of parasites as trophic tracers has thus far been limited to marine ecosystems, but, given the ubiquity of parasites (Marcogliese, 2004), implementation of this method in other ecosystems is certainly possible (see Holmstad et al., 2004). Additional advantages of parasites are that they provide information even when their host's stomach is empty (Baldwin et al., 2008) and indicate long-term feeding, as they can accumulate in their hosts for months or longer (Marcogliese and Cone, 1997). However, this method also requires that the animals are killed and dissected, the method is time-consuming and considerable taxonomic expertise is required. Some of these shortcomings might be overcome using DNA barcoding, which is inexpensive ( $\sim 5 € /$ parasite), or by coupling behavioural and molecular approaches (Poulin, 2010). However, the use of a parasite as a biological tag relies on an at least partial understanding of the parasite's life cycle, which probably explains their use mostly in fish species so far.

\subsection{Tracers of biomass}

Trophic tracers of biomass origin are elements or molecules that an organism can gain only from its trophic resources. The presence of a tracer in the biomass of an organism indicates the consumption and assimilation of a resource containing that tracer, as well as whether and how much the different trophic resources have contributed to the biomass of the organism (or its targeted tissue), provided that the potential resources differ in their tracer composition. Moreover, the presence of a tracer not only reflects the consumption of a resource, it can also provide an information on how the tracer is retained and transferred within the consumer, such as by selective digestion or assimilation (Gannes et al., 1997) or routing to different tissues (Carleton et al., 2008).

\subsubsection{Stable isotope composition of bulk tissues}

One of the most common trophic-tracer-based methods is the determination of the stable isotope composition of bulk tissues, such as muscle, blood, liver, feather, hair, fin, or whole organism. In trophic ecology, C, N and S are the tracers most frequently used in stable isotopic analysis (SIA) (Fry, 2006), but H/D and O isotopes are also employed (Vander Zanden et al., 2016). The method is based on predictable differences (trophic discrimination factors, TDFs) between the isotopic composition of an organism and that of its food resources. For $\mathrm{C}$ and $\mathrm{S}$, the difference is limited and these elements are mainly used to trace the origins of the food resources from which the consumers' biomass has been synthesized (Boecklen et al., 2011), whereas the TDF for $\mathrm{N}$ is larger, allowing its use in estimates of trophic position (Post, 2002). However, the variability in the TDFs depending on environments, trophic levels, taxa, tissues, etc. (Bond and Diamond, 2011) is a potential confounding factor, that has been highlighted in several studies (e.g. Bastos et al., 2017). In addition, the high variability of stable isotope compositions in space and time (e.g. Hyndes et al., 2013) must also be considered. Several tools are used to analyse stable isotope data. Their most recent versions generally adopt a similar Bayesian approach to account for the sources of uncertainty (e.g. Parnell et al., 2013) and include associated confidence intervals. Bayesian approaches also allow introducing informative priors, increasing the accuracy and precision of the estimates. We distinguished three main types of tools: (1) those devoted to the estimation of trophic position (e.g. tRophicPosition, Quezada-Romegialli et al., 2018), (2) isotopic metrics to measure specimen or species positions in the isotopic space and to compare the variability of isotopic signatures across individuals, populations and communities (SIBER, Jackson et al., 2011; Cucherousset and Villéger, 2015) and (3) mixing models to estimate the contribution of each potential trophic resource to the biomass of an organism (see Philips, 2012 for a review). The relevance of SIA-derived results is thus strongly tied to isotopic discrimination between resources, the spatial and temporal variability of the isotopic compositions captured by resource/consumer sampling and an accurate estimate of the TDF. SIA is not well suited to situations involving large numbers of potential resources (e.g. Robinson et al., 2018). The integration of the food isotopic signal into the consumer's tissue depends of the rate at which tissue are renewed, by somatic growth or metabolic tissue replacement (which determines isotopic turnover). Issues related to isotopic turnover thereby limit the relevance of the method for individuals (i.e. adults) or seasons of reduced somatic growth (gonadic growth or maintenance metabolism, Perga and Gerdeaux, 2005). Issues related to differential isotopic routing (Gannes et al., 1998; Del Rio et al., 2009) and unequal TDF in plant versus animal food sources (Perga and Grey, 2010) also limit the detection of omnivory for individuals and species exploiting both plant and animal resources. As a result, SIA enables quantitative estimates of elemental fluxes within the different steps and habitats of a food web, but it is a less than ideal method with which to assess the diversity and specificity of a consumer's diet.

When natural isotope abundance does not provide the necessary discrimination between sources, for example, to overcome uncertainties linked to TDF variability, small quantities of isotopically labelled 
sources (stable or radioactive) can be injected in- or ex-situ to track $\mathrm{C}$ and/or N pathways. This method of isotope labelling, or Stable Isotope Probing (SIP) aims to track the integration of the labelled elements within food webs (Pace et al., 2007). Primary producers can be selectively labelled through addition of ${ }^{13} \mathrm{C}$-enriched bicarbonate/carbon dioxide or ${ }^{15} \mathrm{~N}$-enriched ammonium or nitrate directly in situ (see e.g. Middelburg et al., 2000) to track the fate of primary production through food webs. Similarly, SIP based on dissolved organic matter (e.g. Hall and Meyer, 1998), phytodetritus (e.g. Scharnweber et al., 2014) or animal faeces (e.g. Dungait et al., 2009) are used to label microbial decomposers and the fate of dead organic matter through "brown" food webs. The mode (single addition, pulse chase, or constant levels) and the duration (a few hours to several months) at which the label is introduced into the system determine the time and scale at which the fate of the labelled substrate is tracked (from microbial interactions up to the whole ecosystem), and eventually to document the dynamics of the processes (when performed in pulse chase) (e.g. Maxfield et al., 2012). If studies using isotope labelling are relieved from the issues of TDF uncertainties encountered for SIA in natural abundances, they also suffer for issues related to isotope routing. Indeed, structural components of plant material behave differently than metabolic components in terms of microbial utilisation, grazing, and assimilation (see e.g. Soong et al., 2014). The success of isotope-labelling experiments is thereby strongly tied to the ability to uniformly label throughout the food source, or instead to differentially label the structural and metabolic components of the source (Soong et al., 2014). SIP studies have proven powerful in documenting microbial involvement in biogeochemical processes in soils and sediments and in quantifying the trophic links between the microbial and macro-faunal worlds (e.g. Crotty et al., 2012; Middelburg, 2014).

\subsubsection{Fatty acid trophic biomarkers}

Since the early 1980s, fatty acids (FAs) have been widely used to study predator-prey relationships and to trace the origin and transfer of organic matter in food webs (St-John and Lund, 1996). The use of FAs as trophic markers relies on the specific FA patterns exhibited by basal resources that are then transferred to and identifiable in consumers. As such, FAs have been analysed in many species to infer feeding relationships in aquatic environments for example (Arts et al., 2009). They are increasingly used to shed light on feeding channels in soil environments (e.g. Ruess et al., 2007). Most often, this method requires tracing specific FAs of prey that cannot be synthesized de novo by the tar-

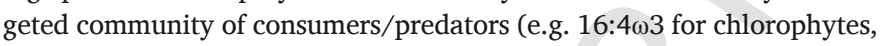

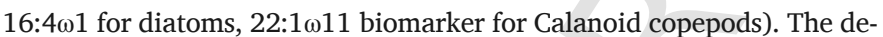
tection of those prey-specific FAs in the tissues of consumers/predators thus reveals the assimilation pathway of the prey. However, many fatty acids (e.g. 16:0, 18:0, 18:3 $103,18: 2 \omega 6$ ) occur in a wide range of organisms restraining the accuracy of the approach (Dalsgaard et al., 2003). For this matter, the comparison of FA ratios can improve the interpretation of results (Parrish, 2013). For example tracking the16:1 $\omega 7 / 16: 0$ ratio for diatoms or the $22: 6 \omega 3 / 20: 5 \omega 3$ ratio for chrysophytes can be used to demonstrate that these microalgae are assimilated by zooplanktonic microcrustaceans (Desvilettes et al., 1997; Pepin et al., 2011). Indeed, the reliability of FA-based trophic markers requires in-depth knowledge of the lipid metabolism of both primary producers and the targeted animal species as a prerequisite. However, while these metabolic processes may obscure the identification of actual food resources, FA-based methods generally provide sufficient information on foraging patterns.

To date, most studies using FA have been qualitative with the presence/absence of a source-specific FA being used as an indicator of the existence of a trophic interaction between this source and the consumer under study. A Quantitative FA Signature Analysis (QFASA) has been more recently developed to enable the estimation of the propor- tions of different sources in a predator's diet (Iverson et al., 2004). Basically, the FA signatures of consumers are modelled as a mixture of the FA signatures of major food resources, which provides a quantitative estimate of the proportions of those resources. The method is based on the calculation of the statistical distance between predator FA signatures and mean prey FA signatures. The predator's FA patterns are corrected according to the degree of modification linked to its FA metabolism. Calibration coefficients are then necessary and calculated using experimental diet studies. These studies are designed to assess the selective retention of dietary fatty acids, to detect fatty acid bioconversion or de novo synthesis. The acceptance of this method by researchers studying the trophic ecology of marine mammals for example will likely be broadened by the recent development of a dedicated R-package (Bromaghin, 2017). According to Happel et al. (2016), however, as for mixing models in SIA, the use of QFASA should be limited to the predators that consume a small number of species and that can be studied experimentally as well as in the wild.

\subsubsection{Compound specific isotopic analyses (CSIA)}

Combining detection of biomarkers (lipids and amino-acids mainly, but also amino-sugars) to stable isotope analyses, CSIA is able to trace the sources and pathways of numerous natural as well as anthropogenic organic compounds. In ecology, first utilizations of CSIA focused on chemotaxonomic markers of microorganisms. Although the role of microorganisms is crucial in processing and transferring organic matter in food webs, their isotopic signatures were rarely reported due to the difficulty of isolating specific microbial biomass from natural samples. Using ${ }^{13} \mathrm{C}$ labelled substrates Boschker et al. (1998) described a CSIA approach to directly link specific microbial processes with the organism involved, based on the stable carbon isotope labelling of individual lipid biomarkers. In the same way, Werne et al. (2002) followed the ${ }^{13} \mathrm{C}$ depleted signal of methane in cold seep sediment through different specific microbial markers and could trace with smart elegance the flow of methane-derived-carbon through anaerobic methane-oxidizing archaea (archeol and sn-3-hydroxyarchaeol) into sulfate-reducing bacteria (C15 and C17 iso and anteiso fatty acids, dialkyl glycerol diethers), as well as into aerobic methane-oxidizing bacteria (diploptene, diplopterol) up to bacterivorous ciliates (tetrahymanol). Stable isotope probing of amino-sugars is regarded as a promising tool to investigate fungal-bacterial interactions in soils (Bodé et al., 2013). Thus, CSIA can be used successfully for elucidating source and fate of naturally or artificially labelled substrates.

In other cases, the isotopic fractionation between substrates and chemotaxonomic markers must be known. Food webs studies have thus applied CSIA on essential lipid compounds such PUFA or sterols by assuming that TDFs would be negligible. However, an unpredictable fractionation ranging from $0 \%$ to $4 \%$ o still occurs during trophic transfer of essential lipid compounds such sterols (Chamberlain et al., 2004) or PUFA (Bec et al., 2011; Gladyshev et al., 2016). Moreover, the intermolecular variability of $\delta^{13} \mathrm{C}$ values within the same sample may be relatively high, thereby challenging again data interpretation. For example, the difference between fatty acids $\delta^{13} \mathrm{C}$ values within a single cultivated alga may be up to $7.6 \%$ (Schouten et al., 1998). Thus, interpretation of CSIA data could be constrained in case the potential endmembers are not sufficiently isotopically different. However, when the conditions are met, CSIA could trace limiting compounds and eventually detect minor food sources unseen by classical methods. For example, CSIA has revealed an uncoupling between essential compounds and major organic matter transfers highlighting functional importance of minor food sources of great nutritional importance (Koussoroplis et al., 2010). An increasing attention is now being paid to amino acids-CSIA since McClelland and Montoya (2002) showed that the $\delta^{15} \mathrm{~N}$ values of some amino acids such phenylalanine in consumers are very similar to those in the producers while the $\delta^{15} \mathrm{~N}$ values of other amino 
acids such glutamic acid become enriched in ${ }^{15} \mathrm{~N}$ with each trophic transfer. Thus, due to this differential ${ }^{15} \mathrm{~N}$ enrichment with trophic transfer, $\delta^{15} \mathrm{~N}$ of amino acids in a consumer provide a measurement of the $\delta^{15} \mathrm{~N}$ baseline as well as its trophic position.

Coupled with stable isotopic probing (also coined SIP), ribosomal RNA or DNA can also be used as integrative tracers. ${ }^{13} \mathrm{C}$ - or ${ }^{15} \mathrm{~N}$-labelled RNA or DNA is heavier and can be separated from unlabelled material using isopycnic ultracentrifugation, for example. Further amplification and barcoding of the isolated fractions allows an organism associated with the assimilation of a specific resource or organic contaminant to be identified (Neufeld et al., 2007). In microbial ecology, this is a promising approach to detect specific functional guilds of microbes (e.g. methanotrophic bacteria), but it can also be scaled-up to other consumers, such as fungi and flagellates, to reveal matter flows in microbial food webs (Lueders et al., 2003).

\subsubsection{Contaminants as trophic tracers}

Both trace metals (inorganic elements) and xenobiotic organic compounds can fulfil the role of trophic tracers (Ramos and González-Solís, 2011) when these contaminants enter trophic pathways and differentially bio-accumulate in food sources or prey and consequently in consumers or top predators (e.g. Walters et al., 2008; Pitt et al., 2017). Selected contaminants can thus be used to infer trophic relationships, including the prey preferences of consumers/predators, foraging areas or food webs exploited by different individuals or populations (e.g., Larsson et al., 1990; Deshpande et al., 2016) and even trophic positions and organic matter flux when bio-magnification occurs (Kelly et al., 2007). Therefore, these indirect tracers can be particularly helpful when there is inherent difficulty of direct observations of trophic relationships (e.g., for marine species). Another advantage of using contaminants in a trophic perspective is that it also informs on the contamination status of the species and food webs of concern, which may be very interesting for ecotoxicological and/or conservation biology perspectives as well. For example, a survey of cadmium (Cd) in common dolphins from the North-East Atlantic allowed neritic and oceanic populations to be distinguished based on the Cd concentrations in their kidneys (long-term accumulation organ in mammals) and their distinct preferential prey (Lahaye et al., 2005). Cephalopods and especially oceanic squids (i.e. the preferential prey of oceanic dolphins compared to neritic ones) indeed display very high burden of this metal relative to fish prey species, and were thus proved to constitute a significant vector of Cd for their predators (Caurant and Amiard-Triquet, 1995; Bustamante et al., 1998).

However, while monitoring contaminants can yield information on both trophic interactions and matter fluxes, good knowledge of the contaminants' characteristics (biogeochemical cycles, the distribution and persistence of the contaminant in organisms and the environment), the target organism's biology, and the structure of food webs are essential. Another prerequisite is an obvious source of the contaminant and its clear partitioning. In fact, contaminants are rarely used alone as trophic tracer tools, and rather complement other intrinsic trophic markers such as C, N, S isotopic ratios or FA profiles (e.g., Krahn et al., 2007; Hebert et al., 2009; Praca et al., 2011). For example, in prey with similar FA but different contaminant profiles, use of the latter allows the discrimination of different diets in the predator (while the use of FA alone did not). Nevertheless, the use of contaminants as trophic tracers requires that the analysed tissues be carefully chosen, because the type of tissue strongly influences the turnover rate of the contaminant-containing compound, which in turn modifies the integration time of the contaminant itself. Finally, like parasites-based approaches, the toxic effects of a contaminant may alter the feeding strategy of the organism. However, as long as the contaminants are able to track these potentially altered foraging behaviours, they fulfil their role as trophic tracers. With the recent development and improvement of modelling tools such as the "Ecotracer" module (Walters and Christensen, 2018) in the Ecopath with Ecosim software package (see Sections 3.3 and 5.1), the potential of contaminants as trophic tracers could be further extended.

\section{Connecting species within networks from ecological data (inference methods)}

Because establishing complete inventories of trophic interactions within a system is virtually impossible, inference methods can be used to reconstruct trophic networks when the ecological datasets are incomplete (Jordano, 2016). Inference methods are thus specifically useful when empirical approaches (such as those described in Section 2) cannot be implemented to assess trophic interactions. In that case, inference methods combine empirical data about the community composition (mostly occurrence/abundance of the different species) and theoretical knowledge about trophic ecology (e.g. trophic behaviour of the species) to infer the trophic interactions within the community. It is worth noting that inference methods were not specifically developed for trophic interactions, but for all kinds of interactions (from causal relationships among variables, to social networks). Several ways are available to infer interactions (e.g. using Gaussian distributions, logical interaction rules or likelihood postulates), each leading to a different method that can be applied to trophic interactions. In the following, we only focus on the inference methods that are mainly used in the reconstruction of trophic networks.

\subsection{Graphical models}

A Graphical model is a probalistic model using a graph to represent the dependencies among variables. In the case of trophic networks, the variables are species abundances or occurrences and the edges in the graph can be interpreted as trophic interactions. Generally, the graph structure is given by expert knowledge, and graphical models are used to make predictions about species persistence. Conversely, it is also possible to learn the graph structure, in our case the trophic network, using empirical data. The principle is to draw an edge between two species in the community, whenever their abundances/occurrences are not independent. Two main kinds of graphical models are used in trophic ecology: Gaussian Graphical Models (GGMs) (Højsgaard et al., 2012) and Bayesian Networks (BNs) (Jensen and Nielsen, 2007).

With GGMs, independence between two species is assessed from the empirical data with the precision matrix (i.e. the inverse of the covariance matrix of the model). The resulting network is an undirected interaction network whose edges are weighted by the coefficient of the precision matrix. Expert knowledge is then required to determine the nature and the direction of the inferred interactions (trophic or non-trophic links). In addition, it is often necessary to limit the number of inferred interactions to the most relevant ones. To do so, GGMs are coupled with sparse regularisation techniques, such as the graphical LASSO (for Least Absolute Shrinkage and Selection Operator; Friedman et al., 2008). Faisal et al. (2010) tested different GGM procedures on large-scale spatial data sets describing abundance records for 39 species of European Warblers. They were able to reconstruct in silico the ecological networks, and from the inferred networks, they could compare the relative role of bioclimatic versus biotic interactions on the species spatial distribution.

Unlike GGMs, BNs and their temporally explicit extension, dynamic-BNs (Dean and Kanazawa, 1989) rely on directed graphs. Concretely, it means that an edge can be interpreted directly as a predation link. BNs also differ from GGMs by the learning process of the graph. In the case of BNs, every possible graph is used to assess species abundances/occurrences. Then, each graph receives a score, depending on both the fit between observed and inferred abundances/occurrences 
and graph complexity. Scores are calculated using different statistical score functions (e.g. Bayesian information criterion), but the underlying principle is the same: to find a graph (in our case a trophic network) that maximises the score, exactly or approximately. In trophic ecology, BNs and dynamic-BNs have been successfully applied to infer feeding interactions among species based on synthetic data (Aderhold et al., 2012), by combining expert knowledge and field data, such as long-term catches per unit effort of fisheries (Trifonova et al., 2015), or based on the presence-absence time series of a fish community (Sander et al., 2017).

\subsection{Logic-based approaches}

Logic-based approaches differ from graphical models by the way they reconstruct trophic networks. The principle is not based on statistical approaches, but on a set of logical rules (in the form of: "if" premise "then" consequence) that is used to reconstruct trophic networks. The main advantage of such approaches is to establish the rules by combining background knowledge about the species and their environment and empirical data. In trophic ecology, two techniques are commonly used to determine the set of logical rules: Inductive logic programming (Muggleton, 1991) when background knowledge is available; or meta-interpretive learning (Muggleton et al., 2014) when background knowledge is incomplete or lacking, (e.g. when the trophic ecology of the species is not known and is actually the object of the attention). Logic-based approaches have been successfully employed to automatically generate trophic networks. For instance, Bohan et al. (2011) reconstruct the trophic network of invertebrate communities within arable fields in Great Britain, using logic-based machine-learning algorithms, species occurrence data and background knowledge, such as species body-size and functional groups.

\subsection{Linear inverse inference}

In linear inverse inference, trophic networks are represented in a steady state, as static webs of model compartments (e.g. species or group of species) that are linked together by linear interactions (Van Oevelen et al., 2010). The approach is particularly suited to infer the magnitude of missing interactions, a very common situation in many ecosystems given the high-dimensionality of trophic networks and the scarcity of information across all trophic levels. Linear inverse inference estimates the missing interactions by ensuring mass-balance across all compartments. Practically, different kinds of techniques can be used (see Van Oevelen et al., 2010) to select the set of parameters that produce the best fit between the modelled abundances (or biomasses) of each compartment and empirical observations. The Ecopath software (see Christensen and Pauly, 1992) constitutes a typical example of this approach. In addition, linear inverse inference can be coupled with ecological stoichiometry or stable isotopic analysis to further constrain the solution range of the reconstructed food webs. For instance, Pacella et al. (2013) associated isotope data with linear inverse modelling to reconstruct the feasible food webs within the Marennes-Oléron intertidal seagrass bed.

\subsection{Approximate Bayesian computation}

Bayesian inference methods rely on the computation of a likelihood, which is the probability density of the observed data under the studied model. It is associated with the parameter values of the model. As a likelihood computation is not always possible, approximate Bayesian methods can be used instead, with the most common one being the Approximate Bayesian Computation (ABC). This approach originates from the field of population genetics (Tavaré et al., 1997) but it has been successfully applied in trophic ecology to decipher the im- pacts of trophic interactions on the spatial structure of communities (e.g. Jabot and Bascompte, 2012). In an ABC, the likelihood computation step is replaced by intensive simulations of the model with variable parameter values, so as to select the values that lead to the best match between simulations and empirical data. ABC can be further coupled to efficient algorithms, such as sequential or traditional Markov Chain Monte Carlo methods (Jabot et al., 2013). This approach was used to evidence the presence of density-dependent dispersal in spatially distributed food webs, as well as its implication for food web spatial structure (Melián et al., 2015).

\section{Quantifying the consequences of feeding from individuals to ecosystems}

\subsection{Ecophysiological markers}

Nutritional status and/or body condition can be assessed using diverse types of information, such as foraging success or the energy stored by individuals (Schulte-Hostedde et al., 2001). Using ecophysiological approaches among others, nutritional status and body condition can be helpful to (1) infer feeding activities and foraging history of individuals and populations, and (2) the consequences of trophic relationships and availability of resources on individual health and fitness as well as population and community dynamics. Despite the existence of extremely invasive or lethal methods currently available to assess body condition, body composition and nutritional status, non-lethal techniques are increasingly used. As described in recent reviews, these techniques include body condition indices, body fluid biochemistry, chemical dilution techniques (isotope dilution: change in concentration of isotopes of hydrogen and/or oxygen in body water, and gas dilution: change in concentration of lipid soluble gas), electrical approaches such as body electrical conductivity and bioelectrical impedance, scanning methods (e.g. magnetic resonance imaging, ultrasound scanning, dual-energy X-ray absorptiometry, computed tomography), molecular analyses (e.g. gene expression) and measurements of stress hormones and immune responses (Stevenson and Woods, 2006; Wilder et al., 2016).

In addition, animal performance (i.e. various life-history traits related to fitness, such as survival, development rate and growth, resistance to starvation, tests of stamina, and reproductive success) can be measured. These data are often used to assess the physical condition of the animal, or to evaluate the "quality" of its food and/or habitat and determining factors of trophic interactions or driver of diet selection (Harrison et al., 2011; Jakob et al., 1996; Raubenheimer and Simpson, 2004; Visanuvimol and Bertram, 2011). Metabolism is also a physiological indicator; it can be determined directly through calorimetry, and indirectly through respirometry, which measures the basal metabolic rate (at rest) or the maximum oxygen consumption rate during forced exercise (Sadowska et al., 2008; Urrejola et al., 2011). Among this wide range of techniques, our focus here is on those most widely used, easy to conduct, least invasive and least expensive, namely, body condition indices and body fluid biochemistry.

\subsubsection{Body condition}

Body composition, or the amount of fat vs. fat-free body mass, is probably one of the most direct indicators of body condition. It provides a quantitative assessment of energy storage because lipid stores constitute the principal form of energy reserves in animals (Schulte-Hostedde et al., 2001; Walsberg, 1988). Thus, the body's energy reserves are measured through analyses of body fat content or body composition. The latter is mostly based on two or three compartments: fat mass, lean dry mass/water mass and protein and ash mass (Jakob et al., 1996; Peig and Green, 2009; Reynolds et al., 2009; Schulte-Hostedde et al., 2005). Alternative, but destructive methods, that can 
be conducted in study designs based on carcass collection for instance include the sampling and weighing of specific subcutaneous fat depots during dissection or the use of complementary somatic indices such as those of the liver or pancreas (Stevenson and Woods, 2006). However, such methods are tedious, time-consuming and intrusive as well as destructive.

Consequently, other methods have been proposed to measure body composition or fat stores, notably total body electrical conductivity (Reynolds et al., 2009; Walsberg, 1988), magnetic resonance imaging (McGuire and Guglielmo, 2010) and body composition modelling (Molnar et al., 2009). In certain taxonomic groups (such as birds), subcutaneous adipose depots can be assessed by simple visual inspection (Labocha and Hayes, 2012), whereas others (small mammals) require simple measurements, such as pelvic circumference, considered representative of fat content (Labocha et al., 2014). In microscopic organisms, coherent anti-Stokes Raman spectroscopy can be used to non-invasively observe lipid droplets in tissues (e.g. Fueser et al., 2018).

Body condition indices based on morphometrics have also been developed. Most discriminate between the mass of the individual associated with body structural size (body weight) and the mass related to energy reserves (Green, 2001; Peig and Green, 2009; Schulte-Hostedde et al., 2005). Accordingly, the greater the body weight is, the larger are the energy reserve, and the better is the body condition. Body condition indices thus allow the relative size of the body's energy stores to be computed, taking into account body structural size components. Historically, this was achieved using the residuals of the regression (typically, ordinary least squares regression) between body weight and some index of body size, or by calculating the scaled mass index (Green, 2001; Peig and Green, 2009, 2010; Schulte-Hostedde et al., 2005). Although much debated (Wilder et al., 2016), body condition indices based on morphometrics have been, and are still, widely applied (Labocha et al., 2014; Labocha and Hayes, 2012; Wilder et al., 2016).

\subsubsection{Body fluid biochemistry}

Several (micro-) nutrients needed to fulfil basic energetic requirements and metabolism cannot be synthesized de novo and can only be acquired from food (Kohl et al., 2015; McWilliams, 2011). These essential trace elements include dietary minerals (e.g. $\mathrm{Cu}, \mathrm{Co}, \mathrm{Fe}, \mathrm{Mn}$, Mo, Se, $\mathrm{Zn}$ ), carotenoids, vitamins and some amino acids and FAs (Costantini et al., 2010; Harrison et al., 2011; Kohl et al., 2015; McWilliams, 2011). By measuring the levels of certain metabolites, electrolytes and enzymes, the depletion of some essential or limiting dietary element, and thus the health state (or the presence of food deficiencies) of the individual, can be determined directly. Moreover, information are given on how the resource balance is oriented toward the use (and even storage) of nutrients from the acquired food or toward the mobilisation of endogenous reserves.

With the aid of diagnostic tools similar to those used in human and veterinary medicine, body fluid biochemistry can be used to assess body condition and individual health in other organisms (Resano-Mayor et al., 2016; Schoepf et al., 2017), especially for micro-nutriments only acquired by food. Since the late 1990s, interest in non-lethal methods to evaluate the physiological state of individuals has grown and has stimulated the development of technical devices and commercial kits compatible with the measurement of micro-volumes. Thus, biochemical analyses of plasma/serum or hemolymph can be conducted by measuring various markers related to nutrition and digestion, metabolism, nutrient storage, osmoregulation, liver or kidney function and immunity. Specifically, nutritional status and patterns of energy utilisation can be assessed by measuring the levels of the products of intermediary metabolism related to diet and detectable in body fluids. This is the case for total proteins, glucose, albumin, urea, creatinine, uric acid, essential minerals and trace elements. Lipid metabolism can be assessed by measuring the concentrations of lipids and ketones, homeostasis, energetic metabolism or the functioning of tissues involved in digestion based on the activities of specific enzymes (e.g. alkaline phosphatase, lactate dehydrogenase and creatine kinase). There are also markers specifically associated with starvation, such as bile acids, bilirubin and globulin, and those that allow accurate assessments of hepatic, renal and pancreatic function or electrolyte levels (major and dietary minerals). Analyses of body fluids may also target specific micronutrients essential for normal metabolic processes and thus potentially indicative of health status. An example is carotenoids. These fat-soluble pigments originate from plants, algae or fungi but cannot be synthesized de novo by vertebrates, which must acquire them exclusively from dietary sources. Hence, carotenoid-based traits can reveal the foraging ability, resource availability and trophic interactions as well as the nutritional and immune status of their bearers (Sternalski et al., 2010).

The main drawback of these techniques lies in the difficulty of interpreting the data obtained from the battery of markers. The measured parameters must be chosen carefully to obtain convincing evidence of a metabolic pattern or change in nutritional status. Furthermore, some parameters can be interpreted only in the light of variations in others (for instance lipids or hepatic enzymes), and body fluid biochemistry can be affected by several confounding factors in the relationship with food acquisition (for instance, blood/hemolymph metabolite concentrations may change after food ingestion, and age, sex, and reproductive stage can affect metabolic levels and enzymatic activities). Given these considerations, an integrated assessment is critical and should be based on the use of several body fluid biomarkers, other metrics of body condition and could be dependant of individual and ecological factors as well (Resano-Mayor et al., 2016; Wilder et al., 2016). Changes in physiological conditions are not always food-related but may be driven by other abiotic stressors (e.g. temperature changes, contaminants) that might be considered carefully but that are important in trophic ecology as well as to get further insights into the consequences of the interactions between environmental factors and trophic relationships (see for instance Bustnes et al., 2015). Such issues are raising growing interest within the framework of stress ecology. Nutritional ecology is one side within trophic ecology framework that is perhaps not enough considered to build integrated approaches and may deserve further attention in studies on food webs and trophic ecology (Raubenheimer et al., 2009).

\subsection{Trait-based trophic ecology}

Focusing on functional features rather than on taxa helps describing biodiversity from a functional point of view (Levine, 2016). Trait-based approaches can be an adequate theoretical framework for understanding and predicting food webs dynamics and properties (Bartomeus et al., 2016; Gravel et al., 2016). Thus, trait-based trophic ecology investigates both (1) trophic interactions per se and (2) their ecosystem implications. First, functional traits allow inferences regarding the most probable interactions occurring within a community. A common first approach uses phenological traits or ecological preferences to detect species that co-occur and to discard unlikely trophic interactions (González-Varo and Traveset, 2016). The morphological and/or physiological traits of the co-occurring partners are then used to infer the probability of realised trophic interactions (see Gravel et al., 2016 for a useful framework distinguishing foraging, vulnerability and consumption traits). Because determining all interactions among individuals, even in simple systems, is fairly unattainable, narrowing those interactions using functional traits provides an alternative and can make the mechanistic underpinnings of interactions understandable (e.g. Ibanez et al., 2013). In addition, functional traits enable the different dimensions of the trophic niche to be investigated individually or simultane- 
ously by examining the morphological, physiological, phenological and behavioural determinants of the trophic niche of a particular species (e.g. Spitz et al., 2014).

Two tenets of functional-trait-based approaches are essential in interpreting the implications of the identified trophic interactions. First, 'response and effect traits' link the response of individuals to higher trophic levels or to environmental stressors with the potential effects on lower trophic levels. For instance, plant diversity changes affects functional diversity of arthropods across trophic levels (Ebeling et al., 2018) which might affect ecosystem processes. Second, functional-trait-based approaches can explicitly address intra-specific variability at the individual level (Albert et al., 2011; Rota et al., 2018) and the findings then scaled up to the community and ecosystem levels (e.g. Lavorel and Grigulis, 2012).

The development of functional-traits-based approaches in trophic ecology is still hampered by several limitations and drawbacks, but with recent progress these are being overcome e.g. by using methodological standardization (Moretti et al., 2017). Further, it remains difficult to assess the strength of species interactions (the direct effect that species have on their mutual demography). Nevertheless, it is possible to estimate functional food web relationships by distinguishing (1) the life-history traits which may modulate the strength of an interaction on population growth, from (2) the topological traits which may modulate the pairwise interactions between the predator and its prey, and from (3) the consumption traits which may modulate the per capita interaction strength (Gravel et al., 2016, see also Brousseau et al., 2018). Additionally, the correlation between individual traits and how this lack of independence among traits reflects phylogenetic (evolutionary) constraints remain poorly understood (Poff et al., 2006). Thus, the validity of linking traits to actual trophic functions continues to be a source of debate, as the causal link between them is often far from obvious, quite variable, and/or has yet to be definitively demonstrated.

\subsection{Ecological stoichiometry (ES)}

The consequences of elemental imbalances in ecosystems can be explored using ES approaches, in which the elemental compositions of heterotrophic organisms (generally expressed as C:N or C:P ratios) are considered as far less variable than those of primary producers, at least for most similarly sized taxa (Persson et al., 2010). Based on the law of conservation of matter, ES approaches can predict how organisms are influenced by the mismatch between consumer demand and the elemental supply available in resources (Sterner and Elser, 2002). At the ecosystem scale, measuring imbalances can be used to estimate nutrient transfer efficiency and secondary production (Cebrian et al., 2009). In the presence of excess elements in their food, consumers make use of several coping strategies such as: (1) selecting food with elemental ratios close to their requirements and/or (2) eating food of different qualities but assimilating only those elements that fulfil their requirements while rejecting those available in excess. In the latter case, mass balance models can estimate the amount of excess elements released. Experimental measurements of metazoan's nitrogen and phosphorus excretion rates showed that animals can supply nutrients at rates similar to those of other major nutrient sources and support a large portion of primary production by nutrient recycling (Vanni, 2002; Vanni et al., 2002). Excreted elements reduce nutrient limitations and impact ecosystem processes in a predictable manner (Danger et al., 2009). Accordingly, ES is a powerful conceptual framework for predicting both the consequences of resource ingestion on consumers' life history traits and the ecosystem consequences of elemental imbalances. To date, most ES studies have focused on C, N and P; however, the consideration of other essential elements (e.g. As or $\mathrm{Cu}$, see Karimi and Folt, 2006) might provide a better understanding of nutrient transfer and the potential limitations for consumer growth or ecological processes (Welti et al., 2017).

\subsection{Resource quality}

Parameters other than the C:N:P ratios of resources can influence consumers' growth and physiological status as well as the efficiency of nutrient and energy transfer into food webs. These include several essential compounds as crucial drivers of diet selection (Kohl et al., 2015). For example, the lack of certain polyunsaturated FAs of the $\omega 3$ series and/or phytosterols limits Daphnia growth and/or reproduction (e.g. Martin-Creuzburg et al., 2009). Micronutrients are another example and include carotenoids, described in Section 4.1.2. These pigments are important stimulators of immune responses and show antioxidant properties (e.g. Lucas et al., 2014). Integrative approaches that include large classes of biochemical compounds (proteins, lipids, glucids) have been proposed to relate resource composition and organism fitness within a conceptual framework referred to as "nutritional geometry" (Simpson and Raubenheimer, 1993). Its advantage is that it directly relates consumers' feeding strategies to their life history traits (e.g. optimal carbohydrate/protein ratios that optimize either individual growth or reproduction) and thus nutritional geometry allows evolutionary questions to be explicitly related to trophic ecology. Moreover, a combination of all of these resource-quality-based approaches has been proposed (Sperfeld et al., 2017) and is a promising methodological strategy for research in trophic ecology.

\section{Testing the implications of trophic interactions (trophic models)}

While inference methods are used to reconstruct trophic interactions within community (Section 3), modelling approaches presented in this section allow investigations of the consequences of feeding interactions on various ecosystem features, ranging from population to ecosystem dynamics. The assumptions underlying the different models include continuous/discrete, mechanistic/statistical and individual-/population-based systems. The common goal is to simulate food web functioning from a set of given conditions, such as network structure, which can in some cases be determined through inference methods. Modelling approaches can be used to investigate the potential implications of feeding interactions in terms of community dynamics and/or organic matter/energy transfers (e.g. Rall et al., 2008) and thus contribute to an improved understanding and management of ecosystems. The use of models also allows the testing of hypotheses that cannot be tested in natural systems (e.g. Gaucherel et al., 2017) as well as the formulation of predictions regarding ecosystem responses to management decisions (e.g. Marzloff et al., 2016). In this section, we present the main modelling approaches currently used for hypotheses testing in trophic ecology.

\subsection{Ordinary differential equations and qualitative models}

Ordinary differential equations (ODEs) simulating species dynamics, such as the Lotka-Volterra equations, can be adapted for food web models. The latter have been central to understanding indirect interactions in food webs and in studying the consequences of predator-prey interactions on population dynamics (e.g. Rall et al., 2008). Food web models based on ODEs allow investigations of the relationship between food web complexity and stability (e.g. McCann and Rooney, 2009). During the last two decades, models based on ODEs have been expanded to include allometric constraints on species traits, such as metabolic rates and feeding rates, leading to the so-called bioenergetic or allometric trophic network model (Brose et al., 2017). Ecosim, the time dynamic simulation module associated with Ecopath, is a well- 
known application of this approach and it is commonly used to explore policy options in the ecosystem-based management of fisheries, such as the effects of fishing on ecosystems and the establishment of marine protected areas (see Walters et al., 1997).

Qualitative modelling focuses on the feedback structure of food webs and is used to assess both stability and ecosystem responses to perturbations (Puccia and Levins, 1985). This method, which is also based on ODEs, is particularly well suited for trophic ecology studies, as it does not rely on the quantification of all trophic interactions within a system. Indeed, based only on qualitative assessments of the interactions among major trophic compartments (e.g. positive, neutral or negative), qualitative models of food webs can provide a general understanding of ecosystem stability and dynamics based on network topology (Hulot et al., 2000). For instance, they can be used to predict the overall responses of a community to long-term disturbances, as the spatial shift of multiple marine species due to ocean warming (e.g. Marzloff et al., 2016). However, the predictions are most useful for simple networks ( $<15$ nodes) as they become ambiguous in more complex systems (e.g. Dambacher et al., 2003).

\subsection{Statistical approaches}

Statistical approaches are based on graphical models (see Section 3.1 ), but in the present case, the graph structure (i.e. the trophic network) is known and is not an output of the model. Trophic interactions are represented as edges in the graph and are interpreted as statistical interactions between species by the model. Using the resulting graph, statistical approaches are able to model the probability of species persistence, explicitly, without a mechanistic model of the extinction dynamics. Unlike Lotka-Volterra or structural food-web models that are based on material fluxes, statistical approaches can be built from simple "on-field" observations of individual occurrence. The required experimental set-up is thus simpler than the one for computing the parameters and structure of Lotka-Volterra or structural models. Another advantage is the possibility to evaluate the resilience of trophic networks using the probabilities of species persistence, and not only the trophic structure. McDonald-Madden et al. (2016) adopted this approach to study the conservation management of 6 real food webs (the Alaskan, Baltic Sea, Lake Vattern, Cheasapeake Bay, Arizona Montane forest and Long Island Salt Marsh food webs) and 40 hypothetical food webs. The resulting predictions allow estimating the effect of management strategy directly at the scale of food-web and their study provide a computationally efficient way of identifying the important species to manage in large food webs.

\subsection{Discrete approaches}

In discrete approaches, networks of trophic interactions are represented by systems made of distinct and separate components, and characterised by temporally distinct and separated events (e.g. Campbell et al., 2011). As such, discrete approaches, more than classical trophic models, are particularly appropriate to consider complex interaction networks (i.e. networks with a high number of direct and indirect processes), while their behaviour remain under rigorous control. A strong advantage of discrete models is thus the possibility to model the evolution of trophic networks over time. Studying ecosystem trajectories constitutes a potential fruitful research avenue for discrete approaches that could help identifying sustainable paths (the ecosystem is able to persist and evolve) from dead-ends (the ecosystem disappears or is stuck in a specific state with less interacting species). Gaucherel et al. (2017) followed such an approach, using Boolean networks, to study the trajectories of a theoretical termite colony. By removing different numbers and types of nodes, the authors simulated different disturbances of the colony and examine the effects on the interaction net- work. By doing so, they showed that the colony was highly sensitive to the trophic part of the interaction network. In addition, this example illustrates the conceptual shift permitted by discrete approaches toward broader (spatial and temporal) scales of ecological processes (Wallach et al., 2017).

\subsection{Individual-based models}

In an individual-based model (IBM), each individual and its associated behaviour are represented, which allows interactions among individuals to be approximated. IBMs are commonly used in ecology (Grimm et al., 2005). An important research activity surrounding IBMs consists in understanding how patterns at the population or community scale emerge from the interactions among individuals (Durrett and Levin, 1994). In trophic ecology, IBMs can be used to reveal the consequences of intraspecific variations in diet on community trophic structure (Bolnick et al., 2011) or eco-evolutionary dynamics (Melián et al., 2011). Another application consists in scaling from trait-based interactions between individuals to the global structure of ecological networks (Jabot and Bascompte, 2012).

\subsection{Dynamic energy and mass budget approaches}

The dynamic energy and mass budget (DEB) theory describes the organisation of metabolism within organisms (Sousa et al., 2008) by modelling its quantitative facets (assimilation rate, growth/maintenance, and maturity/reproduction) based on common rules of allocation and the processes occurring at the organism level. Standard DEB model consists in a system of three ordinary differential equations following first order dynamics. Assimilated products first enter a reserve pool which is then mobilized to fuel two pathways following the kappa rule: a fixed kappa fraction is allocated to perform growth and maintenance and the remaining fraction (1-kappa) is available for maturity (i.e. increase of complexity and its maintenance) and reproduction (Van der Meer, 2006). A set of 12 primary parameters is calibrated from life history traits and univariate data (Lika et al., 2011). Common model inputs are temperature and food availability and outputs are size, shape, full life cycle dynamics, reproduction rate and composition of the organism (C, $\mathrm{H}, \mathrm{O}, \mathrm{N}$ ). Standard DEB models (one reserve, isometric organism) are commonly used at the level of the individual organism (e.g. Grangeré et al., 2010) but they can be scaled up to population level (Martin et al., 2012) or to food web and ecosystem levels including trophic interactions (e.g. Marques et al., 2014). Interesting applications of DEB models in trophic ecology are related to diet reconstructions (Picoche et al., 2014), the effect of food stoichiometry on growth (Muller et al., 2001), the effect of prey selection on organism bioenergetics (Lavaud et al., 2014) and spatio-temporal dynamics of predator-prey interaction (Grangeré et al., 2010). With some more parameters, they also include the dynamics of body isotope composition (Pecquerie et al., 2010) and thus offer promising perspectives in understanding metabolically induced variations in TDFs and in the dynamics of isotope incorporation (Emmery et al., 2011), in turn allowing better inferences using natural stable isotope ratios.

\section{A comprehensive toolbox of methods}

Trophic ecology is a vibrant field of research supported, as discussed extensively above, by a diverse and ever-growing array of methodological tools. For ecologists seeking to answer specific trophic questions, we examine this set of tools (Table 1) based on our own experience and background (Fig. 1). For the empirical methods, our discussion includes the results of a multiple correspondence analysis (MCA) based on an evaluation of the price, investment, and affinities of each method with key criteria, such as the observational scale, organi- 
Table 1

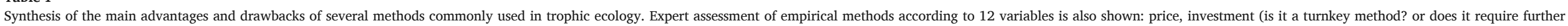

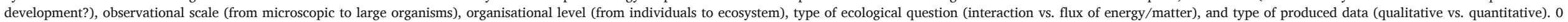

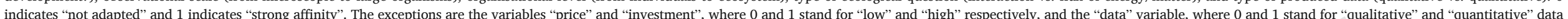
respectively.

\begin{tabular}{|c|c|c|c|c|c|c|c|c|c|c|c|c|c|c|}
\hline $\begin{array}{l}\text { Detecting prey- } \\
\text { predator } \\
\text { relationships, or } \\
\text { food sources }\end{array}$ & Price & Investment & Micro & Small & Large & Individual & Population & Community & Ecosystem & Interaction & Flux & Data & Advantages & Drawbacks \\
\hline $\begin{array}{l}\text { Observation of } \\
\text { feeding } \\
\text { activity }\end{array}$ & 0 & 1 & 0 & 1 & 1 & 1 & 1 & 0 & 0 & 1 & 0 & 1 & $\begin{array}{l}\text { Straightforward and well-established/ } \\
\text { Relatively cheap/Various interactions and } \\
\text { scales (incl. intraspecific variability)/In } \\
\text { situ or under controlled conditions/Large } \\
\text { scale records of feeding-behaviours are } \\
\text { possible with miniaturization of loggers }\end{array}$ & $\begin{array}{l}\text { Temporal \& spatial scales are } \\
\text { design-dependent/Difficult to } \\
\text { measure assimilation }\end{array}$ \\
\hline $\begin{array}{l}\text { Incubation } \\
\text { experiments }\end{array}$ & 0 & 1 & 1 & 1 & 0 & 1 & 1 & 1 & 0 & 1 & 1 & 1 & $\begin{array}{l}\text { Effect-size of specific variables/Suitable } \\
\text { for filter-feeders }\end{array}$ & $\begin{array}{l}\text { Mostly laboratory-based, so } \\
\text { deviation from natural conditions } \\
\text { might occur }\end{array}$ \\
\hline $\begin{array}{l}\text { Gut } \& \text { faeces } \\
\text { content }\end{array}$ & 0 & 1 & 1 & 1 & 1 & 1 & 1 & 0 & 0 & 1 & 0 & 1 & $\begin{array}{l}\text { Well-established/Relatively cheap/ } \\
\text { Information on nature and size of ingested } \\
\text { food items }\end{array}$ & $\begin{array}{l}\text { Snapshot of diet (does not reveal } \\
\text { interaction strength)/Time } \\
\text { consuming/Labile tissues or prey } \\
\text { might be overlooked }\end{array}$ \\
\hline Gut DNA & 1 & 1 & 0 & 1 & 1 & 1 & 1 & 1 & 0 & 1 & 0 & 0 & $\begin{array}{l}\text { Identification of gut microbiomes/Works } \\
\text { on partly digested, poorly recognizable, } \\
\text { food items }\end{array}$ & $\begin{array}{l}\text { Expensive/Susceptible to typical } \\
\text { drawbacks associated to molecular } \\
\text { approaches }\end{array}$ \\
\hline $\begin{array}{l}\text { Parasites as } \\
\text { biological tags }\end{array}$ & 0 & 1 & 0 & 0 & 1 & 1 & 1 & 1 & 0 & 1 & 0 & 0 & $\begin{array}{l}\text { Host specificity/Integration of diet over } \\
\text { long time periods/Potential information } \\
\text { on diet provenance }\end{array}$ & $\begin{array}{l}\text { Lethal/No information on prey size/ } \\
\text { Needs empirical knowledge of life- } \\
\text { cycles (and potentially } \\
\text { biogeography) of parasites/Bias due } \\
\text { to side-effects of parasites on hosts' } \\
\text { health and behaviour }\end{array}$ \\
\hline $\begin{array}{l}\text { Bulk Stable } \\
\text { Isotope } \\
\text { Analysis }\end{array}$ & 0 & 0 & 0 & & 1 & 1 & 1 & 1 & 1 & 0 & 1 & 1 & $\begin{array}{l}\text { Well-established/Relatively cheap/Traces } \\
\text { the carbon and nitrogen food sources in } \\
\text { consumers/Important replication is } \\
\text { possible/suited for in situ as well as } \\
\text { laboratory studies }\end{array}$ & $\begin{array}{l}\text { Turnover times and isotopic } \\
\text { discrimination might vary among } \\
\text { species, tissues and the environment } \\
\text { studied/Not well-suited when a } \\
\text { large number of potential resources } \\
\text { are considered }\end{array}$ \\
\hline $\begin{array}{l}\text { Isotopes as } \\
\text { labels }\end{array}$ & 1 & & 0 & 1 & 1 & 1 & 1 & 1 & 1 & 0 & 1 & 1 & $\begin{array}{l}\text { Trace the fate (timing and scale) of carbon } \\
\text { and nitrogen from microbes to } \\
\text { macroscopic consumers/Differentiation } \\
\text { between } \mathrm{N} \text { and } \mathrm{C} \text { uptake from unlabelled } \\
\mathrm{C} \text { and } \mathrm{N} \text { pools }\end{array}$ & $\begin{array}{l}\text { Difficult to provide quantitative } \\
\text { fluxes/Needs to know turnover } \\
\text { incorporation and routing in tissues } \\
\text { (e.g. issue of uniformly labeling the } \\
\text { food source)/Can be relatively } \\
\text { expensive depending on the scale or } \\
\text { nature of the labeling }\end{array}$ \\
\hline Fatty Acids & 1 & 1 & 1 & 1 & 1 & 1 & 1 & 1 & 1 & 0 & 1 & 0 & $\begin{array}{l}\text { Well-established/Traces flux and } \\
\text { nutritional quality }\end{array}$ & $\begin{array}{l}\text { Non-specific biomarkers/Needs a } \\
\text { priori knowledge of producers' and } \\
\text { consumers' metabolism/relatively } \\
\text { expensive }\end{array}$ \\
\hline
\end{tabular}




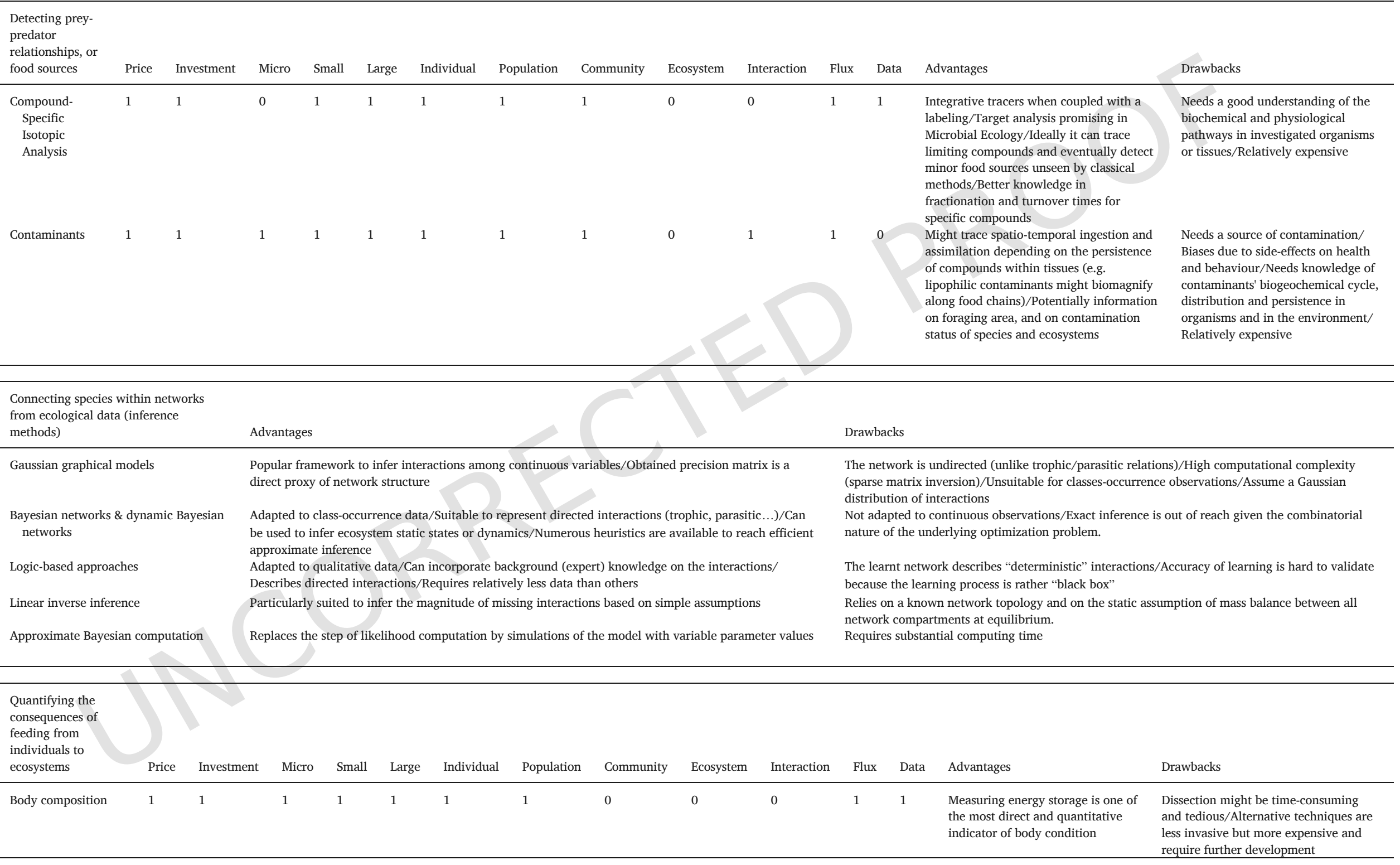




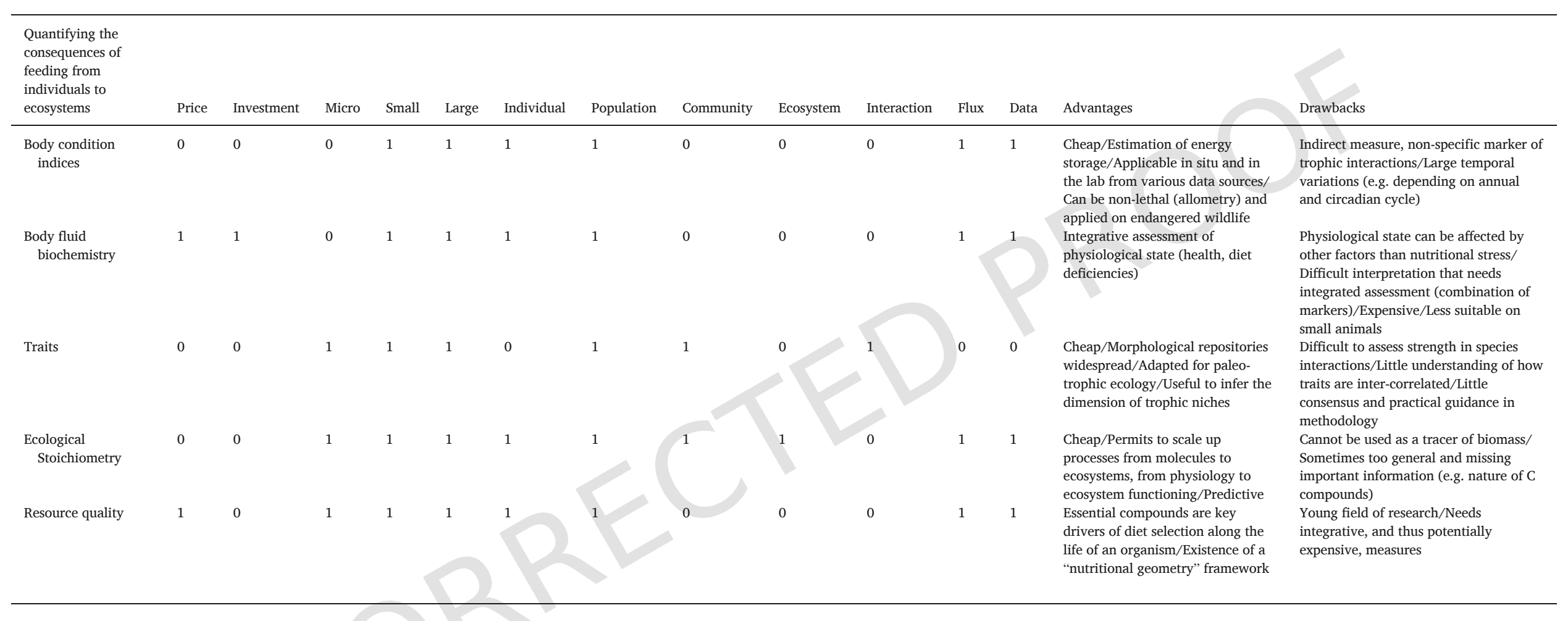

\begin{tabular}{|c|c|c|}
\hline $\begin{array}{l}\text { Testing the implications of } \\
\text { trophic interactions (trophic } \\
\text { models) }\end{array}$ & Advantages & Drawbacks \\
\hline $\begin{array}{l}\text { Ordinary Differential } \\
\text { Equations and qualitative } \\
\text { models }\end{array}$ & $\begin{array}{l}\text { Understanding of indirect interactions and species dynamics in food webs/Qualitative models useful when } \\
\text { the quantification of each trophic interaction is unreachable/Useful to investigate potential consequences } \\
\text { of perturbations on food web functioning and stability }\end{array}$ & $\begin{array}{l}\text { ODE models for large food webs often require a disproportionate number of parameters, and all parameter } \\
\text { combinations are impossible to test through sensitivity analysis/Predictions of the effects of perturbations } \\
\text { with qualitative models become ambiguous for large networks ( }<15 \text { nodes })\end{array}$ \\
\hline Statistical approaches & $\begin{array}{l}\text { Can be built from simple field observations of individual occurrences/Useful to evaluate management } \\
\text { strategies dedicated to increase food web resilience (operational models) }\end{array}$ & $\begin{array}{l}\text { Not process-based, thus no mechanistic understanding/Dependent on collected data (over- and under- } \\
\text { fitting) }\end{array}$ \\
\hline Discrete approaches & $\begin{array}{l}\text { Adapted to discrete and qualitative interactions/Well adapted to large interaction networks, whatever the } \\
\text { nature of components and processes/No need of calibration, except the expert knowledge defining the } \\
\text { model/Relevant to deduce all possible trajectories and stabilities the system may experience. }\end{array}$ & Hardly adapted to continuous quantitative abundances, biomasses or fluxes in the network \\
\hline Individual-based models & $\begin{array}{l}\text { Help understanding how patterns emerge from inter-individual interactions/Able to scale up from trait- } \\
\text { based interactions to structure of ecological networks }\end{array}$ & $\begin{array}{l}\text { Often require very intensive numerical simulations (calibration and validation stages)/Not adapted to } \\
\text { heavy individual or multiscale networks/Hardly provide rigorous and demonstrated analyses }\end{array}$ \\
\hline $\begin{array}{l}\text { Dynamic energy and mass } \\
\text { budget approaches }\end{array}$ & $\begin{array}{l}\text { Model the quantitative facets of metabolism by depicting rules of allocations and processes at the } \\
\text { organism level/Application to diet reconstructions }\end{array}$ & $\begin{array}{l}\text { Huge personal investment required/Decreasing interest when used for complex applications at community } \\
\text { or ecosystem levels }\end{array}$ \\
\hline
\end{tabular}


A

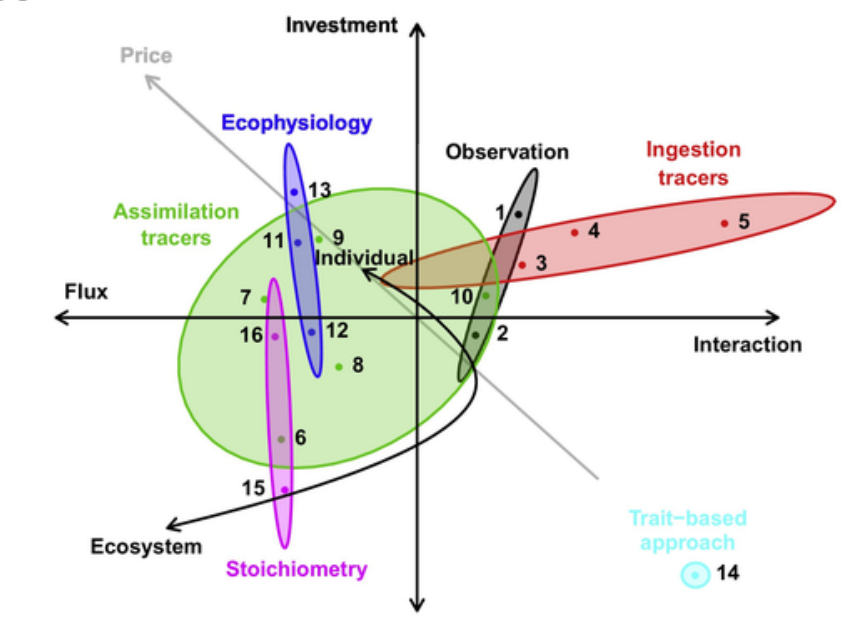

11: Body composition 12: Body condition index 13: Body fluid biochemistry 15: Ecological stoichiometry 16: Resource quality

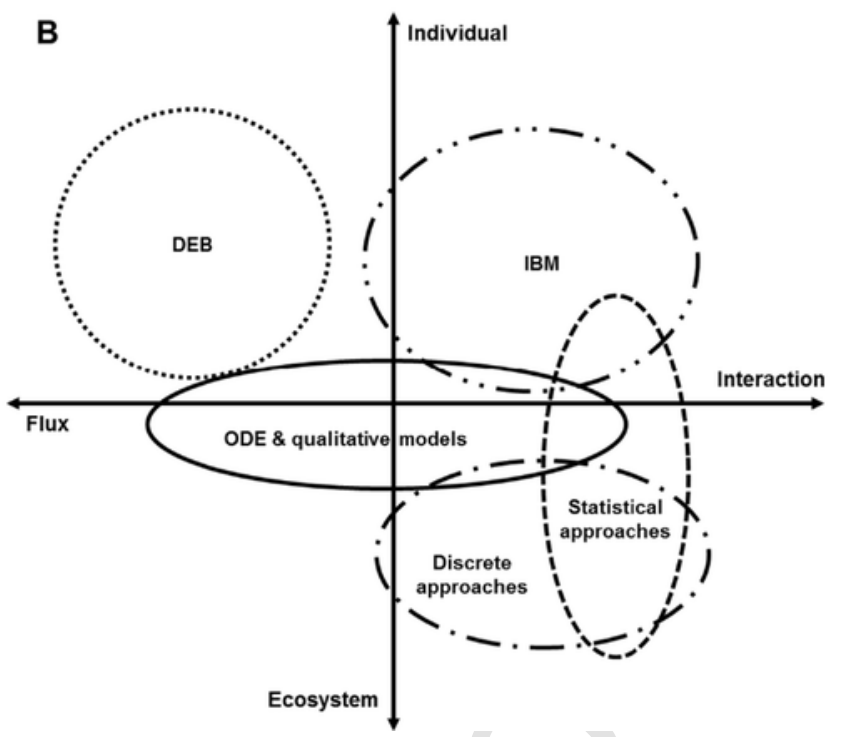

Fig. 1. (A) Multiple correspondence analysis showing the general distribution of empirical methods used in trophic ecology (see Table 1 for data and abbreviations). Arrows indicate the affinity of the methods with the selected features: organisational level (from individuals to ecosystems), ecological questions (interaction vs. flux of energy/matter), or commitment of budget, time and efforts (investment, price). Observational scale (i.e. microscopic to macroscopic) was mostly discriminated by axis 4 , not shown here, but scores are in appendix. (B) Subjective classification of trophic models based on their affinity with the organisational level and ecological question (after C. Gaucherel and E. Thébault, pers. com.). ODE: ordinary differential equation, IBM: individual-based model, DEB: dynamic energy and mass budget.

sational level, type of ecological question to be tackled and the type of data produced (Fig. 1A; the procedure is detailed in the Appendix). The first axis of the MCA was mainly driven by the type of ecological question and the second axis was related to the investment needed to implement the methods. On the same figure (Fig. 1A), we also displayed the methods' affinity with organisational level and a rough evaluation of their costs. We completed this analysis with a subjective classification of the various trophic models (after C. Gaucherel and E. Thébault,

pers. com.). On the resulting Fig. 1B, we focused on the models' affinity with the type of ecological question and organisational level for the sake of consistency with the classification of empirical methods. Not included into this classification were inference methods, because they could not be discriminated by these two axes. The resulting roadmap (Fig. 1A and B) provides an overview of the affinities of the methods for the different criteria. As an example, from Fig. 1A it can be deduced that the use of observational methods is more appropriate than stoichiometry if the nature of feeding interactions is the subject of interest. This visual overview also highlights the gaps (i.e. the absence of available method to address a specific issue), such as the modelling of fluxes at the integrated scale of ecosystems (and not only between species, see Fig. 1B). An advantage of the roadmap is that it facilitates the selection of the best combination of methods with which to investigate (or triangulate) a specific issue in trophic ecology (see below).

\section{Interconnecting approaches to advance ecological research}

The abundance of methods currently available to trophic ecologists offers opportunities such as the triangulation referred to by Munafò and Smith (2018), i.e. the intentional use of multiple approaches which complementarity offers less-biased, multiple lines of evidence. In other words, combining two or more methods allow overcoming the shortfalls of each one alone, and initiating interdisciplinary collaborations that will enrich our knowledge and perspectives. More than combining several methods at the same integration level (e.g. SIA + FA + Gut contents), we recommend more interconnection of approaches, for example by creating first a topology using traits, then modelling and using ingestion/assimilation tracers as validations. Only a few comparative studies of methodologies have been published (but see Nielsen et al., 2018), in the following we present several examples in which complementary methods were merged or interconnected successfully and led to novel insights.

Combinations of methods have been used to improve empirical descriptions of food webs, especially as there are recurring issues related to the integration of trophic processes over time. These can be addressed by complementary approaches. For example, while assimilation tracers such as isotopes and FAs are regularly combined, the addition of complementary behavioural observations and ingestion tracers would favour the emergence of comprehensive theories and models describing tropho-dynamics in food webs (e.g. Woodward et al., 2010; McMeans et al., 2016). Direct field records (motion-sensitive cameras, Robinson et al., 2018) are also useful additional measurements to obtain inferred food webs with a much better temporal accuracy. At the individual level, SIAs can be coupled to DNA-based analyses of gut contents to enable the detection of possible cannibalistic behaviour, as this is not possible with molecular methods (Traugott et al., 2013), and to overcome the lack of dietary resolution inherent to stable isotope methods (e.g. Hambäck et al., 2016).

Other examples show that interconnecting trait-based concepts with stable isotope methods sheds light on the interplay between interactions and fluxes. In fact, this has contributed to the emergence of the concept of isotopic trophic niches (Bowes et al., 2017, and references therein). Also, placing predator-prey functional traits (e.g. predator biting force vs. prey cuticle toughness) within a phylogenetic framework (e.g. evolutionary distance between trophic levels) can give rise to models of predator-prey interactions (Brousseau et al., 2018). Observational data can contribute to inference methods and models to obtain a characterisation of the ecosystem-level properties emerging from trophic interactions (e.g. Pacella et al., 2013; De Vries et al., 2013). For example, a Bayesian model using topology and isotopes was specifically dedicated for the elucidation of trophic strengths in trophic networks (IsoWeb, Kadoya et al., 2012). Models tested against empirical data can be employed to reveal the mechanisms operating within food 
webs and to re-assess the relevant level of complexity (guilds) at which food webs should be scrutinised in the field (Hulot et al., 2000). Theoretical modelling and empirical data, connected through a trait-based approach to species and metabolic rates within allometric trophic networks, can successfully reproduce complex multi-species dynamics in natural environments (Boit et al., 2012). Among the most recent attempts involve hybrid modelling, in which models of the overall dynamics of the ecosystem are combined with realistic individual-based models to link responses at the individual and population levels (Strauss et al., 2017). Also worthy of mention are stoichiometry-based approaches, which offer a powerful and promising perspective from which to extend our knowledge about food webs to include biogeochemical consequences and effects on ecosystem services (Boit et al., 2012; Strauss et al., 2017). A stoichiometric-trait-based approach was recently described (Meunier et al., 2017), although it requires further development (Welti et al., 2017). Multivariate DEB models (several substrates, or/and reserves and structures) offer new perspectives to integrate nutritional geometry and ecological stoichiometry into a metabolic theory through the concept of organisms' homeostasis (Sperfeld et al., 2017). Capturing complex trophic interactions within or between species could then be modelled by embedding multivariate DEB models in agent-based modelling approaches (Sperfeld et al., 2017). Finally, DEB models estimate key morphological traits, such as size, weight, shape, ingestion rates, and range of temperature tolerance. By doing so, they provide connections to biophysical models (e.g. temperature, wind speed and radiation) and to nutritional geometry that allow modelling trophic and ecological niches of organisms (Kearney et al., 2010).

\section{Including the microbial world in trophic ecology}

The microbial world has long been treated almost independently from the macroscopic world (Prosser et al., 2007). Conversely, studies of microbial diversity do not explicitly consider the concepts of trophic ecology. The emergence of molecular approaches has enabled microbial cryptic diversity to be revealed through genomics, by mapping co-occurrence networks within microbial communities (Barberán et al., 2012; Peura et al., 2015). However, the implications of the results in terms of trophic interactions within microbial communities or in relation to the metazoan food web remain poorly explored (Peura et al., 2015). On the other hand, trophic ecology has not yet explicitly integrated the role and contribution of complex microbial communities even though the participation of microbes in aquatic and marine food webs was described more than four decades ago (Pomeroy, 1974), and heterotrophic protists have been recognized as the major grazers in the oceans (Calbet and Landry, 2004; Sherr and Sherr, 2007). Bacterial and micro-eukaryotic communities are for the most part included in food web models as broad, unresolved taxonomic or functional groups, with very few exceptions (Peura et al., 2015; D'Alelio et al., 2016; Weitere et al., 2018). Furthermore, estimates of trophic chain length fail to consider heterotrophic microbes (Post, 2002), while recent CSIA-based assessments register heterotrophic microbes in food webs at the same trophic positions as animals (Steffan et al., 2015).

Consequently, our understanding of the "green" and "brown" food webs, including the tropho-dynamic processes of the detritusphere, emphasised already by Lindeman (1942), remains deficient, and the potential contribution of the topology of microbial and metazoan networks to ecosystem stability and resilience barely known (Peura et al., 2015). Several recent methodological developments may be the first steps in ground-breaking advances in our understanding of micro-macro food webs: (1) Recent developments in DNA-SIP (Pepe-Ranney et al., 2016) and RNA-SIP (Kramer et al., 2016) allow the tracking and identification of microbial metabolisers of organic substrates up to primary consumers (see Section 2.4.3), thereby improving empirical de- scriptions of the links within prokaryotes and protists but also allowing a quantification of the connection to higher trophic levels. (2) By taking advantage of the surge of metagenomic and metatranscriptomic approaches, microbial ecologists have been able to link microbial genetic diversity with the functionalities and biogeochemical processes determined in field samples (see Morales and Holben, 2011 and references therein). (3) Information on taxon-specific feeding selection and the rates measured in experimental settings from microbial and metazoan organisms can be used as input in Ecopath-like food web models adapted to explicitly include highly resolved protozoan contributors (D'Alelio et al., 2016). These models can then be applied to explore the functional consequences of the switches in microbial food web structure on the overall trophic transfer of matter across the micro-macro continuum (D'Alelio et al., 2016). Ecological stoichiometry (Welti et al., 2017) or the application of trait-based approaches to microorganisms (Litchman et al., 2015) may serve as a bridge between the microbial food web and the energetics and biogeochemistry of the ecosystem, while allometric scaling could connect processes at the food web scale, thus merging the "green" and "brown" food chains (e.g. Mulder et al., 2013).

For trophic ecologists, these elements well evidence the so-far-unrealised opportunity to fully consider vertical biodiversity based on an explicit representation of the micro- and macroscopic actors and their roles. With the improvement of the collaboration between microbiologists and trophic ecologists many long-standing questions will finally be answered and "complexity made simple" (Pomeroy, 2001).

\section{Conclusion}

In a world of fast and dynamical changes in environmental conditions, there is a crucial need to understand and anticipate changes in biodiversity in both space and time. Direct effects of changes in physical factors on species depend on specific tolerance, physiological acclimation, phenotypic plasticity and evolutionary processes (Angert et al., 2013), likely to create local changes of biodiversity such as spatial redistribution of species (Marzloff et al., 2016). Yet, evidences are piling that indirect effects of global changes through alterations in species interactions overweight direct effects (see Holt and Barfield, 2009; Angert et al., 2013), or that species range shifting can induce new trophic cascades, inflating the ecological consequences of multiple species redistribution (Marzloff et al., 2016). Such observations of the crucial role of feeding interactions in the biodiversity response to global changes place trophic ecology at the core of the issue (see R. Holt contribution to Nature 2020 visions, Norvig et al., 2010). Recent conceptual and methodological developments in trophic ecology now allow to explore all the dimensions of such changes, but also to draw cross-scale linkages, at least for some pilot sites and case studies. Numerical improvements and machine-learning technics offer the opportunity to test theories and capitalize on these laboriously obtained field- or lab- data by expanding the time- and space scales of processes and predictions (Faisal et al., 2010; Angert et al., 2013). We hope this synthesis will convince our colleagues that we have at hand the perfect toolbox to finally deal with the enormous complexity of trophic implications.

\section{Conflict of interest}

The authors have no competing interests to declare.

\section{Acknowledgements}

This contribution is a collective effort by the French network for trophic ecology (GRET: Groupe de Recherche en Ecologie Trophique), supported by CNRS, INEE and INRA as GDR 3716. We are grateful to 
the numerous members of the GRET who attended workshops in Toulouse and Nantes, where fruitful discussions led to this review. We address many thanks to Craig Layman for his helpful comments on a previous draft of our manuscript. MEP proposed this review and NM, NHT and MEP led, organized and completed the writing. CG provided helpful support for Sections 3 and 5, and ET, AB and MD for Section 7. All authors contributed critically to the drafts and gave final approval of the manuscript for publication.

\section{Appendix A. Supplementary data}

Supplementary data to this article can be found online at https:// doi.org/10.1016/j.fooweb.2018.e00100.

\section{References}

Aderhold, A., Husmeier, D., Lennon, J.J., Beale, C.M., Smith, V.A., 2012. Hierarchical Bayesian models in ecology: reconstructing species interaction networks from nonhomogeneous species abundance data. Ecological Informatics 11, 55-64.

Albert, C.H., Grassein, F., Schurr, F.M., Vieilledent, G., Violle, C., 2011. When and how should intraspecific variability be considered in trait-based plant ecology?. Perspectives in Plant Ecology, Evolution and Systematics 13, 217-225.

Angert, A.L., Ladeau, S.L., Ostfeld, R.S., 2013. Climate change and species interactions: ways forward. Ann. N. Y. Acad. Sci. 1297, 1-7.

Arts, M.T., Brett, M.T., Kainz, M.J., 2009. Lipids in aquatic ecosystems. Springer, New York.

Baker, R., Buckland, S., Sheaves, M., 2014. Fish gut content analysis: robust measures of diet composition. Fish Fish. 15, 170-177.

Baldwin, R.E., Miller, T.W., Brodeur, R.D., Jacobson, K.C., 2008. Expanding the foraging history of juvenile Pacific salmon: combining stomach-content and macroparasitecommunity analyses for studying marine diets. J. Fish Biol. 72, 1268-1294.

Barberán, A., Bates, S.T., Casamayor, E.O., Fierer, N., 2012. Using network analysis to explore co-occurrence patterns in soil microbial communities. The ISME Journal 6, 343-351.

Bartomeus, I., Gravel, D., Tylianakis, J.M., Aizen, M.A., Dickie, I.A., Bernard-Verdier, M., 2016. A common framework for identifying linkage rules across different types of interactions. Funct. Ecol. 30, 1894-1903.

Bastos, R., Corréa, F., Winemiller, K., Garcia, A., 2017. Are you what you eat? Effects of trophic discrimination factors on estimates of food assimilation and trophic position with a new estimation method. Ecol. Indic. 75, 234-241.

Bec, A., Perga, M.-E., Koussoroplis, A., Bardoux, G., Desvilettes, C., Bourdier, G., Mariotti, A., 2011. Assessing the reliability of fatty acid-specific stable isotope analysis for trophic studies. Methods Ecol. Evol. 2, 651-659.

Bodé, S., Fancy, R., Boeckx, P., 2013. Stable isotope probing of amino sugars - a promising tool to assess microbial interactions in soils. Rapid Commun. Mass Spectrom. 27, 1367-1379. https://doi.org/10.1002/rcm.6586.

Boecklen, W.J., Yarnes, C.T., Cook, B.A., James, A.C., 2011. On the use of stable isotopes in Trophic Ecology. Annual Review in Ecology and Evolution Systems 42, 411-440.

Bohan, D.A., Caron-Lormier, G., Muggleton, S., Raybould, A., Tamaddoni-Nezhad, A., 2011. Automated discovery of food webs from ecological data using logic-based machine learning. PLoS One 6, e29028.

Boit, A., Martinez, N.D., Williams, R.J., Gaedke, U., 2012. Mechanistic theory and modelling of complex food-web dynamics in Lake Constance. Ecol. Lett. 15, 594-602.

Bolnick, D.I., Amarasekare, P., Araujo, M.S., Bürger, R., Levine, J.M., Novak, M., Rudolf, V.H.W., Schreiber, S.J., Urban, M.C., Vasseur, D.A., 2011. Why intraspecific trait variation matters in community ecology. Trends Ecol. Evol. 26, 183-192.

Bond, A.L., Diamond, A.W., 2011. Recent Bayesian stable-isotope mixing models are highly sensitive to variation in discrimination factors. Ecol. Appl. 21, 1017-1023.

Boschker, H.T.S., Nold, S.C., Wellsbury, P., Bos, D., 1998. Direct linking of microbial populations to specific biogeochemical processes by 13C-labelling of biomarkers. Nature 392,801

Bowes, R.E., Thorp, J.H., Reuman, D.C., 2017. Multidimensional metrics of niche space for use with diverse analytical techniques. Scientific Reports 7, (srep41599).

Bromaghin, J.F., 2017. QFASAR: quantitative fatty acid signature analysis with R. Methods Ecol. Evol. 8, 1158-1162.

Brose, U., Blanchard, J.L., Eklöf, A., Galiana, N., Hartvig, M., Hirt, M., Kalinkat, G., Nordström, M.C., O'Gorman, E.J., Rall, B.C., 2017. Predicting the consequences of species loss using size-structured biodiversity approaches. Biol. Rev. 92, 684-697.

Brousseau, P.-M., Gravel, D., Handa, I.T., 2018. Trait matching and phylogeny as predictors of predator-prey interactions involving ground beetles. Funct. Ecol. 32, 192-202.

Bustamante, P., Caurant, F., Fowler, S.W., Miramand, P., 1998. Cephalopods as a vector for the transfer of cadmium to top marine predators in the north-East Atlantic Ocean. Sci. Total Environ. 220, 71-80.

Bustnes, J.O., Bourgeon, S., Leat, E.H.K., Magnusdóttir, E., Strøm, H., Hanssen, S.A., Petersen, A., Olafsdóttir, K., Borgå, K., Gabrielsen, G.W., Furness, R.W., 2015. Multiple stressors in a top predator seabird: potential ecological consequences of environmental contaminants, population health and breeding conditions. PLoS One 10, e0131769.
Calbet, A., Landry, M.R., 2004. Phytoplankton growth, microzooplankton grazing, and carbon cycling in marine systems. Limnol. Oceanogr. 49, 51-57.

Campbell, C.E., Yang, S., Albert, R., Shea, K., 2011. A network model for plant-pollinator community assembly. Proc. Natl. Acad. Sci. 108, 197-202.

Carleton, S.A., Kelly, L., Anderson-Sprecher, R., Del Rio, C.M., 2008. Should we use one-, or multi-compartment models to describe $13 \mathrm{C}$ incorporation into animal tissues? Rapid Commun. Mass Spectrom. 22, 3008-3014.

Caurant, F., Amiard-Triquet, C., 1995. Cadmium contamination in pilot whales Globicephala melas: source and potential hazard to the species. Mar. Pollut. Bull. 30, 207-210.

Cebrian, J., Shurin, J.B., Borer, E.T., Cardinale, B.J., Ngai, J.T., Smith, M.D., Fagan, W.F., 2009. Producer nutritional quality controls ecosystem trophic structure. PLoS One 4 e4929.

Chamberlain, P.M., Bull, I.D., Black, H.I.J., Ineson, P., Evershed, R.P., 2004. Lipid content and carbon assimilation in Collembola: implications for the use of compound-specific carbon isotope analysis in animal dietary studies. Oecologia 139, 325-335.

Christensen, V., Pauly, D., 1992. Ecopath II - a software for balancing steady-state ecosystem models and calculating network characteristics. Ecol. Model. 61, 169-185.

Clinchy, M., Sheriff, M.J., Zanette, L.Y., 2013. Predator-induced stress and the ecology of fear. Funct. Ecol. 27, 56-65.

Costantini, D., Rowe, M., Butler, M.W., McGraw, K.J., 2010. From molecules to living systems: historical and contemporary issues in oxidative stress and antioxidant ecology: issues in oxidative stress and antioxidant ecology. Funct. Ecol. 24, 950-959.

Crotty, F.V., Adl, S.M., Blackshaw, R.P., Murray, P.J., 2012. Using stable isotopes to differentiate trophic feeding channels within soil food webs. J. Eukaryot. Microbiol. 59, 520-526.

Cucherousset, J., Villéger, S., 2015. Quantifying the multiple facets of isotopic diversity: new metrics for stable isotope ecology. Ecol. Indic. 56, 152-160.

D'Alelio, D., Libralato, S., Wyatt, T., D'Alcalà, M.R., 2016. Ecological-network models link diversity, structure and function in the plankton food-web. Sci. Rep. 6, 21806.

Dalsgaard, J., John, M.S., Kattner, G., Müller-Navarra, D., Hagen, W., 2003. Fatty acid trophic markers in the pelagic marine environment. Adv. Mar. Biol. 46, 225-340.

Dambacher, J.M., Luh, H.-K., Li, H.W., Rossignol, P.A., 2003. Qualitative stability and ambiguity in model ecosystems. Am. Nat. 161, 876-888.

Danger, M., Lacroix, G., Kâ, S., Corbin, D., Lazzaro, X., 2009. Food-web structure and functioning of temperate and tropical lakes: a stoichiometric viewpoint. International Journal of Limnology 45, 11-21.

De Vries, F.T., Thébault, E., Liiri, M., Birkhofer, K., Tsiafouli, M.A., Bjørnlund, L., Brach Jørgensen, H., Vincent Brady, M., Christensen, S., de Ruiter, P.C., d'Hertefeldt, T., Frouz, J., Hedlund, K., Hemerik, L., Hol, G.W.H., Hotes, S., Mortimer, S.R., Setälä, H., Sgardelis, S.P., Uteseny, K., van der Putten, W.H., Wolters, V., Bardgett, R.D., 2013. Soil food web properties explain ecosystem services across European land use systems. Proc. Natl. Acad. Sci. 110, 14296-14301.

Dean, T., Kanazawa, K., 1989. A model for reasoning about persistence and causation. Comput. Intell. 5, 142-150.

Del Rio, C.M., Wolf, N., Carleton, S.A., Gannes, L.Z., 2009. Isotopic ecology ten years after a call for more laboratory experiments. Biol. Rev. 84, 91-111.

Derycke, S., De Meester, N., Rigaux, A., Creer, S., Bik, H., Thomas, W.K., Moens, T., 2016. Coexisting cryptic species of the Litoditis marina complex (Nematoda) show differential resource use and have distinct microbiomes with high intraspecific variability. Mol. Ecol. 25, 2093-2110.

Deshpande, A.D., Dickhut, R.M., Dockum, B.W., Brill, R.W., Farrington, C., 2016. Polychlorinated biphenyls and organochlorine pesticides as intrinsic tracer tags of foraging grounds of bluefin tuna in the northwest Atlantic Ocean. Mar. Pollut. Bull. 105, 265-276.

Desvilettes, C., Bourdier, G., Amblard, C., Barth, B., 1997. Use of fatty acids for the assessment of zooplankton grazing on bacteria, protozoans and microalgae. Freshw. Biol. $38,629-637$.

Duffy, D.C., Jackson, S., 1986. Diet studies of seabirds: a review of methods. Colonial Waterbirds 9 (1), 17.

Dungait, J.A.J., Bol, R., Bull, I.D., Evershed, R.P., 2009. Tracking the fate of dung-derived carbohydrates in a temperate grassland soil using compound-specific stable isotope analysis. Org. Geochem. 40, 1210-1218.

Dupuy, C., Rossignol, L., Geslin, E., Pascal, P.-Y., 2010. Predation of mudflat meio-macrofaunal metazoans by a calcareous foraminifer, Ammonia tepida (Cushman, 1926). J. Foraminifer. Res. 40, 305-312.

Durrett, R., Levin, S., 1994. The importance of being discrete (and spatial). Theor. Popul. Biol. 46, 363-394.

Ebeling, A., Rzanny, M., Lange, M., Eisenhauer, N., Hertzog, L.R., Meyer, S.T., Weisser, W.W., 2018. Plant diversity induces shifts in the functional structure and diversity across trophic levels. Oikos 127, 208-219.

Eitzinger, B., Micic, A., Körner, M., Traugott, M., Scheu, S., 2013. Unveiling soil food web links: new PCR assays for detection of prey DNA in the gut of soil arthropod predators. Soil Biol. Biochem. 57, 943-945.

Elser, J.J., Dobberfuhl, D.R., MacKay, N.A., Schampel, J.H., 1996. Organism size, life history, and N:P stoichiometry. Bioscience 46, 674-684.

Emmery, A., Lefebvre, S., Alunno-Bruscia, M., Kooijman, S.A.L.M., 2011. Understanding the dynamics of $\delta 13 \mathrm{C}$ and $\delta 15 \mathrm{~N}$ in soft tissues of the bivalve Crassostrea gigas facing environmental fluctuations in the context of dynamic energy budgets (DEB). J. Sea Res. 66, 361-371

Faisal, A., Dondelinger, F., Husmeier, D., Beale, C.M., 2010. Inferring species interaction networks from species abundance data: a comparative evaluation of various statistical and machine learning methods. Ecological Informatics 5, 451-464. 
Friedman, J., Hastie, T., Tibshirani, R., 2008. Sparse inverse covariance estimation with the graphical lasso. Biostatistics 9, 432-441.

Fry, B., 2006. Stable Isotope Ecology. Springer, Berlin.

Fueser, H., Majdi, N., Haegerbaeumer, A., Pilger, C., Hachmeister, H., Greife, P., Huser, T., Traunspurger, W., 2018. Analyzing life-history traits and lipid storage using CARS microscopy for assessing effects of copper on the fitness of Caenorhabditis elegans. Ecotoxicol. Environ. Saf. 156, 255-262.

Gannes, L.Z., O'Brien, D.M., Del Rio, C.M., 1997. Stable isotopes in animal ecology: assumptions, caveats, and a call for more laboratory experiments. Ecology 78, 1271-1276.

Gannes, L.Z., Del Rio, C.M., Koch, P., 1998. Natural abundance variations in stable isotopes and their potential uses in animal physiological ecology. Comparative Biochemistry and Physiology A 119, 725-737.

Garvey, J.E., Whiles, M.R., 2017. Trophic Ecology. CRC Press, Boca Raton, FL.

Gaucherel, C., Théro, H., Puiseux, A., Bonhomme, V., 2017. Understand ecosystem regime shifts by modelling ecosystem development using Boolean networks. Ecol. Complex. 31, 104-114.

Gladyshev, M.I., Makhutova, O.N., Kravchuk, E.S., Anishchenko, O.V., Sushchik, N.N., 2016. Stable isotope fractionation of fatty acids of Daphnia fed laboratory cultures of microalgae. Limnologica 56, 23-29.

González-Varo, J.P., Traveset, A., 2016. The labile limits of forbidden interactions. Trends Ecol. Evol. 31, 700-710.

Grangeré, K., Lefebvre, S., Bacher, C., Cugier, P., Ménesguen, A., 2010. Modelling the spatial heterogeneity of ecological processes in an intertidal estuarine bay: dynamic interactions between bivalves and phytoplankton. Mar. Ecol. Prog. Ser. 415, 141-158.

Gravel, D., Albouy, C., Thuiller, W., 2016. The meaning of functional trait composition of food webs for ecosystem functioning. Philosophical Transasctions of the Royal Society B 371, 20150268.

Green, A.J., 2001. Mass/length residuals: measures of body condition or generators of spurious results?. Ecology 82, 1473-1483.

Grimm, V., Revilla, E., Berger, U., Jeltsch, F., Mooij, W.M., Railsback, S.F., Thulke, H.-H., Weiner, J., Wiegand, T., DeAngelis, D.L., 2005. Pattern-oriented modeling of agent-based complex systems: lessons from ecology. Science 310 (5750), 987-991.

Hall, R.O., Meyer, J.L., 1998. The trophic significance of bacteria in a detritus-based stream food web. Ecology 79, 1995-2012.

Hambäck, P.A., Weingartner, E., Dalén, L., Wirta, H., Roslin, T., 2016. Spatial subsidies in spider diets vary with shoreline structure: complementary evidence from molecular diet analysis and stable isotopes. Ecology and Evolution 6, 8431-8439.

Happel, A., Stratton, L., Kolb, C., Hays, C., Rinchard, J., Czesny, S., 2016. Evaluating quantitative fatty acid signature analysis (QFASA) in fish using controlled feeding experiments. Can. J. Fish. Aquat. Sci. 73, 1222-1229.

Harrison, X.A., Blount, J.D., Inger, R., Norris, D.R., Bearhop, S., 2011. Carry-over effects as drivers of fitness differences in animals: carry-over effects in animal populations. J. Anim. Ecol. 80, 4-18.

Hebert, C.E., Weseloh, D.V.C., Gauthier, L.T., Arts, M.T., Letcher, R.J., 2009. Biochemical tracers reveal intra-specific differences in the food webs utilized by individual seabirds. Oecologia 160, 15-23.

Heidemann, K., Ruess, L., Scheu, S., Maraun, M., 2014. Nematode consumption by mite communities varies in different forest microhabitats as indicated by molecular gut content analysis. Exp. Appl. Acarol. 64, 49-60.

Ho, T.W., Hwang, J.-S., Cheung, M.K., Kwan, H.S., Wong, C.K., 2017. DNA-based study of the diet of the marine calanoid copepod Calanus sinicus. J. Exp. Mar. Biol. Ecol. 494, $1-9$.

Højsgaard, S., Edwards, D., Lauritzen, S., 2012. Gaussian graphical models. In: Graphical Models with R. Use R!. Springer, Berlin.

Holmstad, P.R., Holstad, , Karbøl, G., Revhaug, J.O., Schei, E., Vandvik, V., Skorping, A., 2004. Parasite tags in ecological studies of terrestrial hosts: a study on ptarmigan (Lagopusspp.) dispersal. Ornis Fennica 81, 128-136.

Holt, R.D., Barfield, M., 2009. Trophic interactions and range limits: the diverse roles of predation. Proc. R. Soc. B Biol. Sci. 276, 1435-1442.

Hulot, F.D., Lacroix, G., Lescher-Moutoue, F., Loreau, M., 2000. Functional diversity governs ecosystem response to nutrient enrichment. Nature 405, 340-344.

Hyndes, G., Hanson, C., Vanderklift, M., 2013. The magnitude of spatial and temporal variation in $\delta^{15} \mathrm{~N}$ and $\delta^{13} \mathrm{C}$ differs between taxonomic groups: implications for food web studies. Estuar. Coast. Shelf Sci. 119, 176-187.

Ibanez, S., Manneville, O., Miquel, C., Taberlet, P., Valentini, A., Aubert, S., Coissac, E., Colace, M.-P., Duparc, Q., Lavorel, S., 2013. Plant functional traits reveal the relative contribution of habitat and food preferences to the diet of grasshoppers. Oecologia 173, 1459-1470.

Iverson, S.J., Field, C., Bowen, W.D., Blanchard, W., 2004. Quantitative fatty acid signature analysis: a new method of estimating predator diets. Ecol. Monogr. 74, 211-235.

Jabot, F., Bascompte, J., 2012. Bitrophic interactions shape biodiversity in space. Proc Natl. Acad. Sci. 109, 4521-4526.

Jabot, F., Faure, T., Dumoulin, N., 2013. EasyABC: performing efficient approximate Bayesian computation sampling schemes using R. Methods Ecol. Evol. 4, 684-687.

Jackson, A.L., Parnell, A.C., Inger, R., Bearhop, S., 2011. Comparing isotopic niche widths among and within communities: SIBER - Stable Isotope Bayesian Ellipses in R. J. Anim. Ecol. 80, 595-602.

Jakob, E.M., Marshall, S.D., Uetz, G.W., 1996. Estimating fitness: a comparison of body condition indices. Oikos 77, 61-67.

Jensen, F.V., Nielsen, T.D., 2007. Bayesian Networks and Decision Graphs. Springer, Berlin.
Jordano, P., 2016. Sampling networks of ecological interactions. Funct. Ecol. 30, 1883-1893.

Kadoya, T., Osada, Y., Takimoto, G., 2012. IsoWeb: a Bayesian isotope mixing model for diet analysis of the whole food web. PLoS One 7, e41057.

Karimi, R., Folt, C.L., 2006. Beyond macronutrients: element variability and multielemen stoichiometry in freshwater invertebrates. Ecol. Lett. 9, 1273-1283.

Kearney, M., Simpson, S.J., Raubenheimer, D., Helmuth, B., 2010. Modelling the ecological niche from functional traits. Philos. Trans. R. Soc. B 365, 3469-3483.

Kelly, B.C., Ikonomou, M.G., Blair, J.D., Morin, A.E., Gobas, F.A.P.C., 2007. Food web-specific biomagnification of persistent organic pollutants. Science 317, 236-239.

King, R.A., Read, D.S., Traugott, M., Symondson, W.O.C., 2008. Molecular analysis of predation: a review of best practice for DNA-based approaches. Mol. Ecol. 17, 947-963.

Klein-Breteler, W.C.M., Schogt, N., Baas, M., Schouten, S., Kraay, G.W., 1999. Trophic upgrading of food quality by protozoans enhancing copepod growth: role of essential lipids. Mar. Biol. 135, 191-198.

Kohl, K.D., Coogan, S.C.P., Raubenheimer, D., 2015. Do wild carnivores forage for prey or for nutrients?. BioEssays 37, 701-709.

Koussoroplis, A.-M., Bec, A., Perga, M.-E., Koutrakis, E., Desvilettes, C., Bourdier, G., 2010 Nutritional importance of minor dietary sources for leaping grey mullet Liza saliens (Mugilidae) during settlement: insights from fatty acid d13C analysis. Mar. Ecol. Prog. Ser. 404, 207-217.

Krahn, M.M., Herman, D.P., Matkin, C.O., Durban, J.W., Barrett-Lennard, L., Burrows, D.G., Dahlheim, M.E., Black, N., Leduc, R.G., Wade, P.R., 2007. Use of chemical tracers in assessing the diet and foraging regions of eastern North Pacific killer whales. Mar. Environ. Res. 63, 91-114.

Kramer, S., Dibbern, D., Moll, J., Huenninghaus, M., Koller, R., Krueger, D., Marhan, S., Urich, T., Wubet, T., Bonkowski, M., Buscot, F., Lueders, T., Kandeler, E., 2016. Resource partitioning between bacteria, fungi, and protists in the detritusphere of an Agricultural Soil. Front. Microbiol. 2016 (7), (1524).

Kusmer, K.D., 1990. Taphonomy of owl pellet deposition. J. Paleontol. 64, 629-637.

Labocha, M.K., Hayes, J.P., 2012. Morphometric indices of body condition in birds: a review. J. Ornithol. 153, 1-22.

Labocha, M.K., Schutz, H., Hayes, J.P., 2014. Which body condition index is best?. Oikos 123, 111-119.

Lahaye, V., Bustamante, P., Spitz, J., Dabin, W., Das, K., Pierce, G.J., Caurant, F., 2005 Long-term dietary segregation of short-beaked common dolphins (Delphinus delphis) in the Bay of Biscay determined using cadmium as an ecological tracer. Mar. Ecol. Prog. Ser. 305, 275-285.

Larsson, P., Woin, P., Knulst, J., 1990. Differences in uptake of persistent pollutants for predators feeding in aquatic and terrestrial habitats. Holarct. Ecol. 13, 149-155.

Lavaud, R., Flye-Sainte-Marie, J., Jean, F., Emmery, A., Strand, O., Kooijman, S.A.L.M., 2014. Feeding and energetics of the great scallop, Pecten maximus, through a DEB model. J. Sea Res. 94, 5-18.

Lavorel, S., Grigulis, K., 2012. How fundamental plant functional trait relationships scale-up to trade-offs and synergies in ecosystem services. J. Ecol. 100, 128-140.

Layman, C.A., Giery, S.T., Buhler, S., Rossi, R., Penland, T., Henson, M.N., Bogdanoff, A.K., Cove, M.V., Irizarry, A.D., Schalk, C.M., Archer, S.K., 2015. A primer on the history of food web ecology: fundamental contributions of fourteen researchers. Food Webs 4 $14-24$.

Legler, J.M., Sullivan, L.J., 1979. The application of stomach-flushing to lizards and anurans. Herpetologica 35, 107-110.

Levine, J.M., 2016. Ecology: a trail map for trait-based studies. Nature 529, 163-164.

Lika, K., Kearney, M.R., Freitas, V., Van Der Veer, H.W., Van Der Meer, J., Wijsman, J.W.M., Pecquerie, L., Kooikman, S.A.L.M., 2011. The "covariation method" for estimating the parameters of the standard Dynamic Energy Budget model I: philosophy and approach. J. Sea Res. 66, 270-277.

Linchant, J., Lisein, J., Semeki, J., Lejeune, P., Vermeulen, C., 2015. Are unmanned aircraft systems (UASs) the future of wildlife monitoring? A review of accomplishments and challenges. Mammal Rev. 45, 239-252.

Lindeman, R.L., 1942. The trophic-dynamic aspect of ecology. Ecology 23, 399-417.

Litchman, E., Edwards, K.F., Klausmeier, C.A., 2015. Microbial resource utilization traits and trade-offs: implications for community structure, functioning, and biogeochemical impacts at present and in the future. Front. Microbiol. 6, 254.

Lotka, A.J., 1925. Elements of Physical Biology. 495pp Waverly Press, Baltimore, MD.

Lucas, A., Morales, J., Velando, A., 2014. Differential effects of specific carotenoids on oxidative damage and immune response of gull chicks. J. Exp. Biol. 217, 1253-1262.

Lueders, T., Wagner, B., Claus, P., Friedrich, M.W., 2003. Stable isotope probing of rRNA and DNA reveals a dynamic methylotroph community and trophic interactions with fungi and protozoa in oxic rice field soil. Environ. Microbiol. 6, 60-72.

MacKenzie, K., 2002. Parasites as biological tags in population studies of marine organisms: an update. Parasitology 124, 153-163.

MacKenzie, K., Abaunza, P., 1998. Parasites as biological tags for stock discrimination of marine fish: a guide to procedures and methods. Fish. Res. 38, 45-56.

Majdi, N., Tackx, M., Traunspurger, W., Buffan-Dubau, E., 2012. Feeding of biofilm-dwelling nematodes examined using HPLC-analysis of gut pigment contents. Hydrobiologia 680, 219-232.

Marcogliese, D.J., 2004. Parasites: small players with crucial roles in the ecological theater. EcoHealth 1, 151-164.

Marcogliese, D.J., Cone, D.K., 1997. Parasite communities as indicators of ecosystem stress. Parasitologia 39, 227-232.

Marques, G.M., Mateus, M., Domingos, T., 2014. Can we reach consensus between marine ecological models and DEB theory? A look at primary producers. J. Sea Res. 94, 92-104. 
Martin, B.T., Zimmer, E.I., Grimm, V., Jager, T., 2012. Dynamic energy budget theory meets individual-based modelling: a generic and accessible implementation. Methods Ecol. Evol. 3, 445-449.

Martin-Creuzburg, D., Sperfeld, E., Wacker, A., 2009. Colimitation of a freshwater herbivore by sterols and polyunsaturated fatty acids. Philos. Trans. R. Soc. B 276, 1805-1814.

Marzloff, M.P., Melbourne-Thomas, J., Hamon, K.G., Hoshino, E., Jennings, S., Putten, I.E., Pecl, G.T., 2016. Modelling marine community responses to climate-driven species redistribution to guide monitoring and adaptive ecosystem-based management. Glob. Chang. Biol. 22, 2462-2474.

Maxfield, P.J., Dildar, N., Hornibrook, E.R.C., Stott, A.W., Evershed, R.P., 2012. Stable isotope switching (SIS): a new stable isotope probing (SIP) approach to determine carbon flow in the soil food web and dynamics in organic matter pools. Rapid Commun. Mass Spectrom. 26, 997-1004.

McCann, K.S., Rooney, N., 2009. The more food webs change, the more they stay the same. Philos. Trans. R. Soc. B 364, 1789-1801.

McClelland, J.W., Montoya, J.P., 2002. Trophic relationships and the nitrogen isotopic composition of amino acids in plankton. Ecology 83, 2173-2180.

McDonald-Madden, E., Sabbadin, R., Game, E.T., Baxter, P.W.J., Chadès, I., Possingham, H.P., 2016. Using food-web theory to conserve ecosystems. Nat. Commun. 7, 10245.

McGuire, L.P., Guglielmo, C.G., 2010. Quantitative magnetic resonance: a rapid, noninvasive body composition analysis technique for live and salvaged bats. J. Mammal. 91, 1375-1380.

McMeans, B.C., McCann, K.S., Tunney, T.D., Fisk, A.T., Muir, A.M., Lester, N., Shuter, B., Rooney, N., 2016. The adaptive capacity of lake food webs: from individuals to ecosystems. Ecol. Monogr. 86, 4-19.

McWilliams, S.R., 2011. Ecology of vertebrate nutrition. In: eLS. John Wiley \& Sons Ltd, Chichester http://www.els.net.

Melián, C.J., Vilas, C., Baldo, F., Gonzalez-Ortegon, E., Drake, P., Williams, R.J., 2011. Eco-evolutionary dynamics of individual-based food webs. Adv. Ecol. Res. 45, $225-268$

Melián, C.J., Křivan, V., Altermatt, F., Starý, P., Pellissier, L., De Laender, F., 2015. Dispersal dynamics in food webs. Am. Nat. 185, 157-168.

Meunier, C.L., Boersma, M., El-Sabaawi, R., Halvorson, H.M., Herstoff, E.M., Van de Waal, D.B., Vogt, R.J., Litchman, E., 2017. From elements to function: toward unifying ecological stoichiometry and trait-based ecology. Frontiers in Environmental Science 5,

Mialet, B., Majdi, N., Tackx, M., Azémar, F., Buffan-Dubau, E., 2013. Selective feeding of Bdelloid rotifers in river biofilms. PLoS One 8, e75352.

Middelburg, J.J., 2014. Stable isotopes dissect aquatic food webs from the top to the bottom. Biogeosciences 11, 2357-2371.

Middelburg, J.J., Barranguet, C., Boschker, H.T.S., Herman, P.M.J., Moens, T., Heip, C.H.R., 2000. The fate of intertidal microphytobenthos carbon: an in situ ${ }^{13} \mathrm{C}$-labeling study. Limnol. Oceanogr. 45, 1224-1234.

Moll, R.J., Millspaugh, J.J., Beringer, J., Sartwell, J., He, Z., 2007. A new 'view' of ecology and conservation through animal-borne video systems. Trends Ecol. Evol. 22, 660-668.

Molnar, P.K., Klanjscek, T., Derocher, A.E., Obbard, M.E., Lewis, M.A., 2009. A body composition model to estimate mammalian energy stores and metabolic rates from body mass and body length, with application to polar bears. J. Exp. Biol. 212, 2313-2323.

Morales, S.E., Holben, W.E., 2011. Linking bacterial identities and ecosystem processes: can 'omic' analyses be more than the sum of their parts?. FEMS Microbiol. Ecol. 72, $2-16$

Moretti, M., Dias, A.T.C., Bello, F., Altermatt, F., Chown, S.L., Azcarate, F.M., Bell, J.R., Fournier, B., Hedde, M., Hortal, J., Ibanez, S., Öckinger, E., Sousa, J.P., Ellers, J., Berg, M.P., 2017. Handbook of protocols for standardized measurement of terrestrial invertebrate functional traits. Funct. Ecol. 31, 558-567.

Muggleton, S., 1991. Inductive logic programming. N. Gener. Comput. 8, 295-318

Muggleton, S.H., Lin, D., Pahlavi, N., Tamaddoni-Nezhad, A., 2014. Meta-interpretive learning: application to grammatical inference. Mach. Learn. 94, 25-49.

Mulder, C., Ahrestani, F.S., Bahn, M., Bohan, D.A., Bonkowski, M., Griffiths, B.S., Guicharnaud, R.A., Kattge, J., Krogh, P.H., Lavorel, S., Lewis, O.T., Mancinelli, G., Naeem, S., Peñuelas, J., Poorter, H., Reich, P.B., Rossi, L., Rusch, G.M., Sardans, J., Wright, I.J., 2013. Connecting the green and brown worlds: allometric and stoichiometric predictability of above- and below-ground networks. Adv. Ecol. Res. 49, 69-175.

Muller, E.B., Nisbet, R.M., Kooijman, S., Elser, J.J., McCauley, E., 2001. Stoichiometric food quality and herbivore dynamics. Ecol. Lett. 4, 519-529.

Munafò, M.R., Smith, G.D., 2018. Robust research needs many lines of evidence. Nature 553, 399-401.

Neufeld, J.D., Dumont, M.G., Vohra, J., Murrell, C.J., 2007. Methodological considerations for the use of stable isotope probing in microbial ecology. Microb. Ecol. 53, 435-442

Nielsen, J.M., Clare, E.L., Hayden, B., Brett, M.T., Kratina, P., 2018. Diet tracing in ecology: method comparison and selection. Methods Ecol. Evol. 9, 278-291.

Norvig, P., Relman, D.A., Goldstein, D.B., Kammen, D.M., Weinberger, D.R., Aiello, L.C., Nicholson, J.K., 2010. 2020 visions. Nature 463, 26-32.

Pace, M.L., Carpenter, S.R., Cole, J.J., Coloso, J.J., Kitchell, J.F., Hodgson, J.R., Middelburg, J.J., Preston, N.D., Solomon, C.T., Weidel, B.C., 2007. Does terrestrial organic carbon subsidize the planktonic food web in a clear-water lake?. Limnol. Oceanogr. $52,2177-2189$.

Pacella, S.R., Lebreton, B., Richard, P., Phillips, D., Dewitt, T.H., Niquil, N., 2013. Incorporation of diet information derived from Bayesian stable isotope mixing models into mass-balanced marine ecosystem models: a case study from the Marennes-Oléron estuary, France. Ecol. Model. 267, 127-137.

Parnell, A., Phillips, D., Bearhop, S., Semmens, B., Ward, E., Moore, J., Jackson, A., Grey, J., Kelly, D., Inger, R., 2013. Bayesian stable isotope mixing models. Environmetrics 24, 387-399.

Parrish, C.C., 2013. Lipids in marine ecosystems. ISRN Oceanography 2013, 604045

Pecquerie, L., Nisbet, R.M., Fablet, R., Lorrain, A., Kooijman, S.A.L.M., 2010. The impact of metabolism on stable isotope dynamics: a theoretical framework. Philos. Trans. R. Soc. B 365, 3455-3468.

Peig, J., Green, A.J., 2009. New perspectives for estimating body condition from mass/ length data: the scaled mass index as an alternative method. Oikos 118, 1883-1891.

Pepe-Ranney, C., Campbell, A.N., Koechli, C.N., Berthrong, S., Buckley, D.H., 2016. Unearthing the ecology of soil microorganisms using a high resolution DNA-SIP approach to explore cellulose and xylose metabolism in soil. Front. Microbiol. 7, 703.

Pepin, P., Parrish, C.C., Head, E.J.H., 2011. Late autumn condition of Calanus finmarchicus in the northwestern Atlantic: evidence of size-dependent differential feeding. Mar. Ecol. Prog. Ser. 423, 155-166.

Perga, M.E., Gerdeaux, D., 2005. 'Are fish what they eat' all year round?. Oecologia 144, 598-606.

Perga, M.E., Grey, J., 2010. Laboratory measures of isotope discrimination factors: comments on Caut, Angulo \& Courchamp (2008, 2009). J. Appl. Ecol. 47, 942-947.

Persson, J., Fink, P., Goto, A., Hood, J.M., Jonas, J., Kato, S., 2010. To be or not to be what you eat: regulation of stoichiometric homeostasis among autotrophs and heterotrophs. Oikos 119, 741-751.

Peura, S., Bertilsson, S., Jones, R.I., Eiler, A., 2015. Resistant microbial cooccurrence patterns inferred by network topology. Appl. Environ. Microbiol. 81, 2090-2097.

Philips, D.L., 2012. Converting isotope values to diet composition: the use of mixing models. J. Mammal. 93, 342-352.

Picoche, C., Legendr, R., Flye-Sainte-Marie, J., Francoise, S., Maheux, F., Simon, B., Gangnery, A., 2014. Towards the determination of mytilus edulis food preferences using the Dynamic Energy Budget (DEB) Theory. PLoS One 9, e109796.

Pierce, G.J., Boyle, P.R., 1991. A review of methods for diet analysis in piscivorous marine mammals. Oceanogr. Mar. Biol. 29, 409-486.

Pitt, J.A., Drouillard, K.G., Paterson, G., 2017. Polychlorinated biphenyl bioaccumulation patterns among Lake Erie lower trophic level consumers reflect species ecologies. Bull. Environ. Contam. Toxicol. 98, 65-70.

Poff, N.L.R., Olden, J.D., Vieira, N.K.M., Finn, D.S., Simmons, M.P., Kondratieff, B.C. 2006. Functional trait niches of north American lotic insects: traits-based ecological applications in light of phylogenetic relationships. J. N. Am. Benthol. Soc. 25, 730-755.

Pomeroy, L.R., 1974. The ocean's food web, a changing paradigm. Bioscience 24, 499-504

Pomeroy, L.R., 2001. Caught in the food web: complexity made simple?. Sci. Mar. 65, $31-40$.

Post, D.M., 2002. Using stable isotopes to estimate trophic position: models, methods, and assumptions. Ecology 83, 703-718.

Post, D.M., Palkovacs, E.P., 2009. Eco-evolutionary feedbacks in community and ecosystem ecology: interactions between the ecological theatre and the evolutionary play. Philos. Trans. R. Soc. B 364, 1629-1640.

Poulin, R., 2010. Parasite manipulation of host behavior: an update and frequently asked questions. Advances in the Study of Behavior 41, 151-186.

Praca, E., Laran, S., Lepoint, G., Thomé, J.P., Quetglas, A., Belcari, P., Sartor, P., Dhermain, F., Ody, D., Tapie, N., Budzinski, H., Das, K., 2011. Toothed whales in the northwestern Mediterranean: insight into their feeding ecology using chemical tracers. Mar Pollut. Bull. 62, 1058-1065.

Prasetiya, F.S., Comeau, L.A., Gastineau, R., Decottignies, P., Cognie, B., Morançais, M., Turcotte, F., Mouget, J.-L., Tremblay, R., 2017. Effect of marennine produced by the blue diatom Haslea ostreariaon behavioral, physiological and biochemical traits of juvenile Mytilus edulisand Crassostrea virginica. Aquaculture 467, 138-148.

Prosser, J.I., Bohannan, B.J.M., Curtis, T.P., Ellis, R.J., Firestone, M.K., Freckleton, R.P., Green, J.L., Green, L.E., Killham, K., Lennon, J.J., Osborn, A.M., Solan, M., Ven Der Gast, C.J., Young, J.P.W., 2007. The role of ecological theory in microbial ecology. Nature Review Microbiology 5, 384-392.

Proulx, S.R., Promislow, D.E.L., Phillips, P.C., 2005. Network thinking in ecology and evolution. Trends Ecol. Evol. 20, 345-353.

Puccia, C.J., Levins, R., 1985. Qualitative Modeling of Complex Systems: An Introduction to Loop Analysis and Time Averaging. Harvard University Press, Cambridge, MA.

Quezada-Romegialli, C., Jackson, A.L., Harrod, C., 2018. tRophicPosition: Bayesian trophic position calculation with stable isotopes. In: R Package Version 0.7.5. https:// cran.r-project.org/package $=$ tRophicPosition.

Rall, B.C., Guill, C., Brose, U., 2008. Food-web connectance and predator interference dampen the paradox of enrichment. Oikos 117, 202-213.

Ramos, R., González-Solís, J., 2011. Trace me if you can: the use of intrinsic biogeochemical markers in marine top predators. Front. Ecol. Environ. 10, 258-266.

Raubenheimer, D., Simpson, S.J., 2004. Organismal stoichiometry: quantifying non-independence among food components. Ecology 85, 1203-1216.

Raubenheimer, D., Simpson, S.J., Mayntz, D., 2009. Nutrition, ecology and nutritional ecology: toward an integrated framework. Funct. Ecol. 23, 4-16.

Resano-Mayor, J., Hernández-Matías, A., Real, J., Parés, F., Moleón, M., Mateo, R., Ortiz-Santaliestra, M.E., 2016. The influence of diet on nestling body condition of an apex predator: a multi-biomarker approach. J. Comp. Physiol. B. 186, 343-362.

Reynolds, D.S., Sullivan, J.C., Kunz, T.H., 2009. Evaluation of total body electrical conductivity to estimate body composition of a small mammal. J. Wildl. Manag. 73, 1197-1206. 
Robinson, B.G., Franke, A., Derocher, A.E., 2018. Stable isotope mixing models fail to estimate the diet of an avian predator. Auk 135, 60-70.

Ropert-Coudert, Y., Wilson, R.P., 2005. Trends and perspectives in animal-attached remote sensing. Front. Ecol. Environ. 3, 437-444.

Rota, T., Jabiol, J., Chauvet, E., Lecerf, A., 2018. Phenotypic determinants of inter-individual variability of litter consumption rate in a detritivore population. Oikos(doi: oik.05228, in press).

Ruess, L., Schütz, K., Migge-Kleian, S., Häggblom, M.M., Kandeler, E., Scheu, S., 2007. Lipid composition of Collembola and their food resources in deciduous forest stands_implications for feeding strategies. Soil Biol. Biochem. 39, 1990-2000.

Sadowska, E.T., Baliga-Klimczyk, K., Chrzascik, K., Koteja, P., 2008. Laboratory model of adaptive radiation: a selection experiment in the bank vole. Physiol. Biochem. Zool. 81, 627-640.

Sander, E.L., Wootton, J.T., Allesina, S., 2017. Ecological network inference from long-term presence-absence data. Sci. Rep. 7, 7154.

Scharnweber, K., Syväranta, J., Hilt, S., Brauns, M., Vanni, M.J., Brothers, S., Köhler, J., Knežević-Jarić, J., Mehner, T., 2014. Whole-lake experiments reveal the fate of terrestrial particulate organic carbon in benthic food webs of shallow lakes. Ecology 95, 1496-1505.

Schoepf, I., Pillay, N., Schradin, C., 2017. The pathophysiology of survival in harsh environments. J. Comp. Physiol. B. 187, 183-201.

Schouten, S., Klein-Breteler, W.C.M., Blokker, P., Schogt, N., Rijpstra, W.I.C., Grice, K., Baas, M., Sinninghe Damsté, J.S., 1998. Biosynthetic effects on the stable carbon isotopic compositions of algal lipids: implications for deciphering the carbon isotopic biomarker record. Geochim. Cosmochim. Acta 62, 1397-1406.

Schulte-Hostedde, A.I., Millar, J.S., Hickling, G.J., 2001. Evaluating body condition in small mammals. Can. J. Zool. 79, 1021-1029.

Schulte-Hostedde, A.I., Zinner, B., Millar, J.S., Hickling, G.J., 2005. Restitution of mass-size residuals: validating body condition indices. Ecology 86, 155-163.

Sherr, E.B., Sherr, B.F., 2007. Heterotrophic dinoflagellates: a significant component of microzooplankton biomass and major grazers of diatoms in the sea. Mar. Ecol. Prog. Ser. 352, 187-197.

Simpson, S.J., Raubenheimer, D., 1993. A multi-level analysis of feeding behaviour: the geometry of nutritional decisions. Philos. Trans. R. Soc. B 342, 381-402.

Soong, J.L., Reuss, D., Pinney, C., Boyack, T., Haddix, M.L., Stewart, C.E., Cotrufo, M.F., 2014. Design and operation of a continuous ${ }^{13} \mathrm{C}$ and ${ }^{15} \mathrm{~N}$ labeling chamber for uniform or differential, metabolic and structural, plant isotope labeling. J. Vis. Exp. 83, 51117.

Sousa, T., Domingos, T., Kooijman, S., 2008. From empirical patterns to theory: a formal metabolic theory of life. Philos. Trans. R. Soc. B 363, 2453-2464.

Sperfeld, E., Wagner, N.D., Halvorson, H.M., Malishev, M., Raubenheimer, D., 2017. Bridging ecological stoichiometry and nutritional geometry with homeostasis concepts and integrative models of organism nutrition. Funct. Ecol. 31, 286-296.

Spitz, J., Ridoux, V., Brind'Amour, A., 2014. Let's go beyond taxonomy in diet description: testing a trait-based approach to prey-predator relationships. J. Anim. Ecol. 83, $1137-1148$.

Steffan, S.A., Chikaraishi, Y., Currie, C.R., Horn, H., Gaines-Day, H.R., Pauli, J.N., Zalapa, J.E., Ohkouchi, N., 2015. Microbes are trophic analogs of animals. Proc. Natl. Acad. Sci. 112, 15119-15124.

Sternalski, A., Mougeot, F., Eraud, C., Gangloff, B., Villers, A., Bretagnolle, V., 2010. Carotenoids in nestling Montagu's harriers: variations according to age, sex, body condition and evidence for diet-related limitations. J. Comp. Physiol. B. 180, 33-43.

Sterner, S.W., Elser, J.J., 2002. Ecological Stoichiometry: The Biology of Elements from Molecules to the Biosphere. Princeton University Press, Princeton, NJ, USA.

Stevenson, R.D., Woods, W.A., 2006. Condition indices for conservation: new uses for evolving tools. Integr. Comp. Biol. 46, 1169-1190.

St-John, M.A.S., Lund, T., 1996. Lipid biomarkers: linking the utilization of frontal plankton biomass to enhanced condition of juvenile North Sea cod. Mar. Ecol. Prog. Ser. $131,75-85$.

Strauss, T., Gabsi, F., Hammers-Wirtz, M., Thorbek, C., Preuss, T.G., 2017. The power of hybrid modelling: an example from aquatic ecosystems. Ecol. Model. 364, 77-88.

Tavaré, S., Balding, D.J., Griffiths, R.C., Donnelly, P., 1997. Inferring coalescence times from DNA sequence data. Genetics 142, 505-518.
Thums, M., Fernández-Gracia, J., Sequeira, A.M.M., Eguíluz, V.M., Duarte, C.M., Meekan, M.G., 2018. How big data fast tracked human mobility research and the lessons for animal movement ecology. Front. Mar. Sci. 5.

Traugott, M., Kamenova, S., Ruess, L., Seeber, J., Plantegenest, M., 2013. Empirically characterising trophic networks: what emerging DNA-based methods, stable isotope and fatty acid analyses can offer. Adv. Ecol. Res. 49, 177-224.

Trifonova, N., Kenny, A., Maxwell, D., Duplisea, D., Fernandes, J., Tucker, A., 2015. Spatio-temporal Bayesian network models with latent variables for revealing trophic dynamics and functional networks in fisheries ecology. Ecological Informatics 30, $142-158$.

Urrejola, S., Nespolo, R., Lardies, M.A., 2011. Diet-induced developmental plasticity in life histories and energy metabolism in a beetle. Rev. Chil. Hist. Nat. 84, 523-533.

Van Oevelen, D., Van den Meersche, K., Meysman, F.J.R., Soetaert, K., Middelburg, J.J., Vézina, A.F., 2010. Quantifying food web flows using linear inverse models. Ecosystems $13,32-45$.

Vander Zanden, H.B., Soto, D.X., Bowen, G.J., Hobson, K.A., 2016. Expanding the isotopic toolbox: applications of hydrogen and oxygen stable isotope ratios to food web studies. Front. Ecol. Evol. 4, 20.

Vanni, M.J., 2002. Nutrient cycling by animals in freshwater ecosystems. Annu. Rev. Ecol. Syst. 33, 341-370.

Vanni, M.J., Flecker, A.S., Hood, J.M., Headworth, J.L., 2002. Stoichiometry of nutrient recycling by vertebrates in a tropical stream: linking species identity and ecosystem processes. Ecol. Lett. 5, 285-293.

Visanuvimol, L., Bertram, S.M., 2011. How dietary phosphorus availability during development influences condition and life history traits of the cricket, Acheta domesticas. J. Insect Sci. 11, 1-17.

Volterra, V., 1926. Fluctuations in the abundance of a species considered mathematically. Nature $118,558-560$

Wallach, A.D., Dekker, A.H., Lurgi, M., Montoya, J.M., Fordham, D.A., Ritchie, E.G., 2017. Trophic cascades in 3D: network analysis reveals how apex predators structure ecosystems. Methods Ecol. Evol. 8, 135-142.

Walsberg, G.E., 1988. Evaluation of a nondestructive method for determining fat stores in small birds and mammals. Physiol. Zool. 61, 153-159.

Walters, W.J., Christensen, V., 2018. Ecotracer: analyzing concentration of contaminants and radioisotopes in an aquatic spatial-dynamic food web model. J. Environ. Radioact. 181, 118-127.

Walters, C., Christensen, V., Pauly, D., 1997. Structuring dynamic models of exploited ecosystems from trophic mass-balance assessments. Rev. Fish Biol. Fish. 7, 139-172.

Walters, D.M., Fritz, K.M., Otter, R.R., 2008. The dark side of subsidies: adult stream insects export organic contaminants to riparian predators. Ecol. Appl. 18, 1835-1841.

Ward, J.E., Shumway, S.E., 2004. Separating the grain from the chaff: particle selection in suspension-and deposit-feeding bivalves. J. Exp. Mar. Biol. Ecol. 300, 83-130.

Weitere, M., Erken, M., Majdi, N., Arndt, H., Norf, H., Reinshagen, M., Traunspurger, W., Walterscheid, A., Wey, J.K., 2018. The food web perspective on aquatic biofilms. Ecol. Monogr.(in press).

Welti, N., Striebel, M., Ulseth, A., Cross, W., Devilbiss, S., Glibert, P., Guo, L., Hirst, A. Hood, J., Kominoski, J., MacNeill, K., Mehring, A., Welter, J., Hillebrand, H., 2017. Bridging food webs, ecosystem metabolism, and biogeochemistry using ecological stoichiometry theory. Front. Microbiol. 8 (1298).

Werne, J.P., Baas, M., Sinninghe-Damsté, J.S., 2002. Molecular isotopic tracing of carbon flow and trophic relationships in a methane-supported benthic microbial community. Limnol. Oceanogr. 47, 16.

Wilder, S.M., Raubenheimer, D., Simpson, S.J., 2016. Moving beyond body condition in dices as an estimate of fitness in ecological and evolutionary studies. Funct. Ecol. 30, $108-115$.

Winemiller, K.O., 1990. Spatial and temporal variation in tropical fish trophic networks. Ecol. Monogr. 60, 331-367.

Woodward, G., Perkins, D.M., Brown, L.E., 2010. Climate change and freshwater ecosystems: impacts across multiple levels of organization. Philos. Trans. R. Soc. B 365, 2093-2106. 